\title{
Economic Analysis for U.S. Geological Survey Coal Basin Assessments
}

Open-File Report 2019-1082 



\section{Economic Analysis for U.S. Geological Survey Coal Basin Assessments}

By Paul E. Pierce

Open-File Report 2019-1082

U.S. Department of the Interior

U.S. Geological Survey 


\title{
U.S. Department of the Interior DAVID BERNHARDT, Secretary
}

\author{
U.S. Geological Survey \\ James F. Reilly II, Director
}

U.S. Geological Survey, Reston, Virginia: 2019

For more information on the USGS - the Federal source for science about the Earth, its natural and living resources, natural hazards, and the environment-visit https://www.usgs.gov or call 1-888-ASK-USGS.

For an overview of USGS information products, including maps, imagery, and publications, visit https://store.usgs.gov.

Any use of trade, firm, or product names is for descriptive purposes only and does not imply endorsement by the U.S. Government.

Although this information product, for the most part, is in the public domain, it also may contain copyrighted materials as noted in the text. Permission to reproduce copyrighted items must be secured from the copyright owner.

Suggested citation:

Pierce, P.E., 2019, Economic analysis for U.S. Geological Survey coal basin assessments: U.S. Geological Survey OpenFile Report 2019-1082, 33 p., https://doi.org/10.3133/ofr20191082.

ISSN 2331-1258 (online) 


\section{Contents}

Abstract

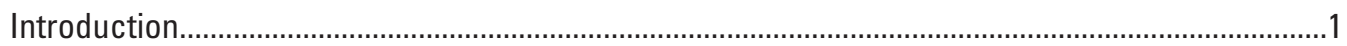

Coal Resources, Mining Methods, and Modeling ............................................................................

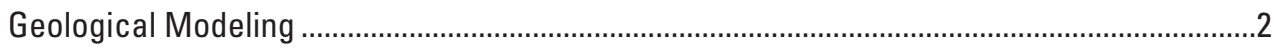

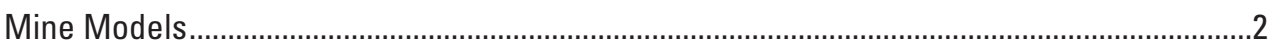

Commercial Mining Economic Studies ..........................................................................

U.S. Geological Survey Mining Economic Studies..........................................................

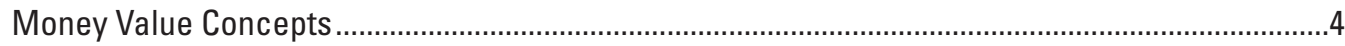

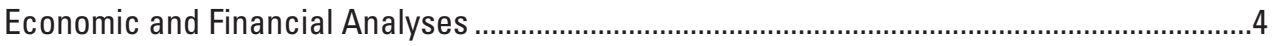

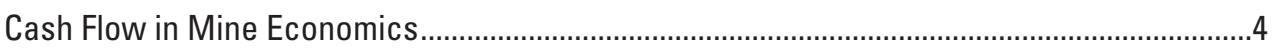

Time Value of Money and Timeline Cost Scheduling ............................................................

Discounted Cash Flow and Net Present Value Analyses..........................................................

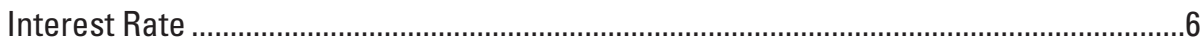

Commercial Mine Economic Analysis.........................................................................

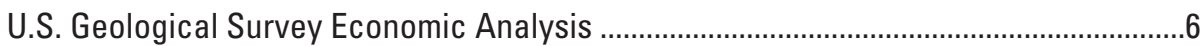

Net Present Value Nomenclature and Calculation ..............................................................

Effect of Life-of-Mine Duration on Net Present Value..............................................................

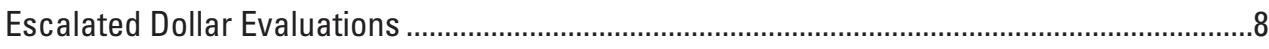

Determining Rates of Interest............................................................................................

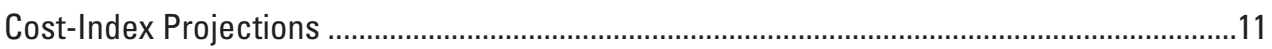

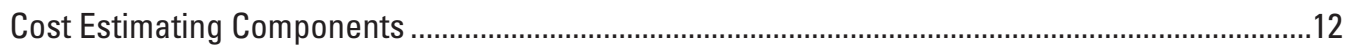

Capital Cost Description and Appropriate Use ....................................................................13

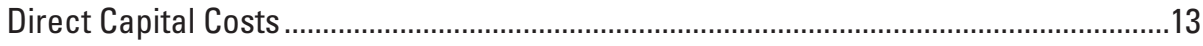

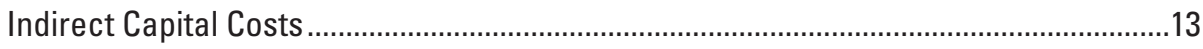

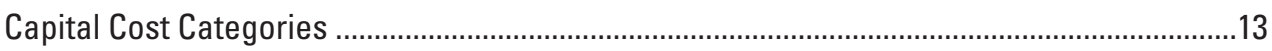

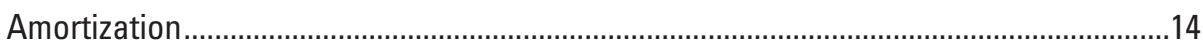

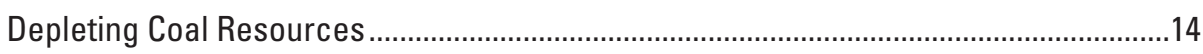

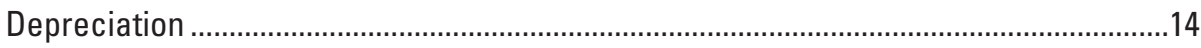

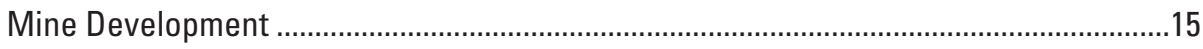

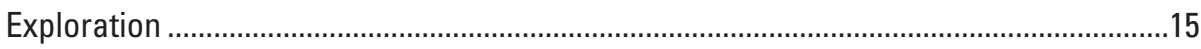

Capital Replacement (Reinvestment) ..........................................................................15

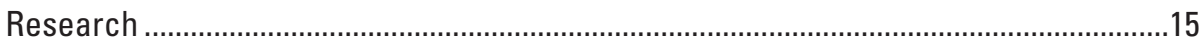

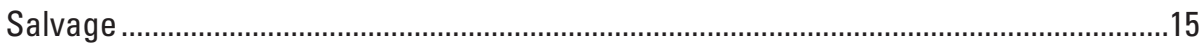

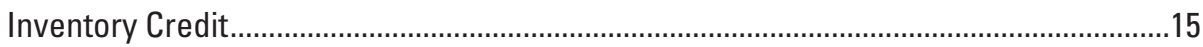

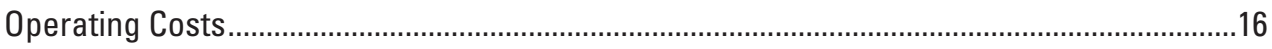

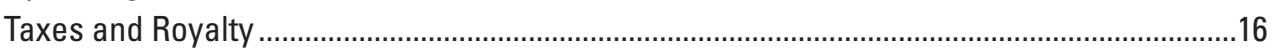

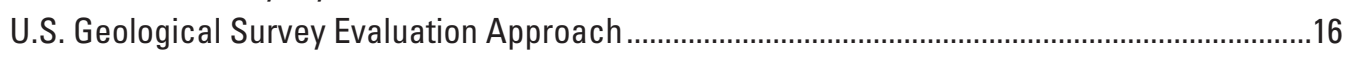

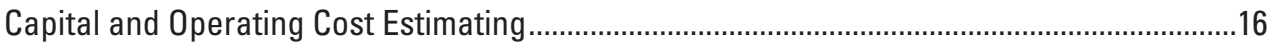

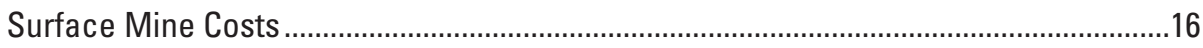

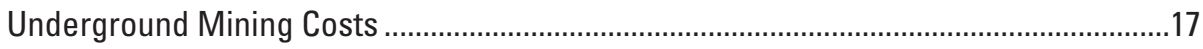

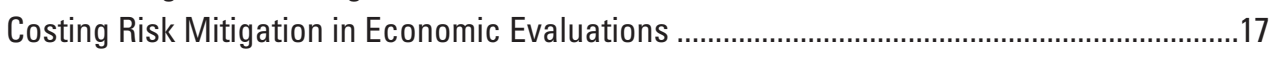

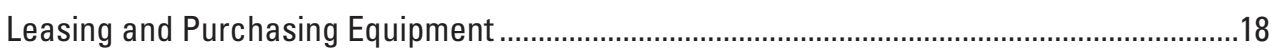

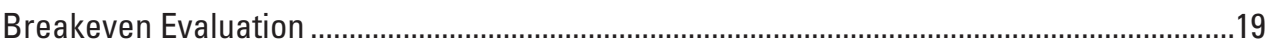

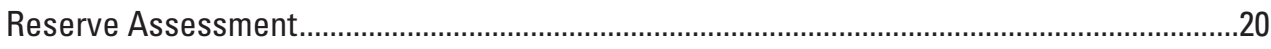

Summary 


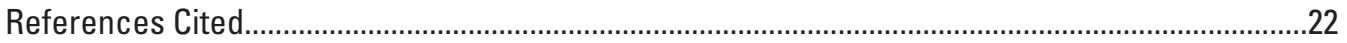

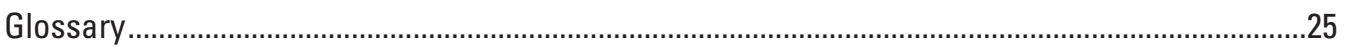

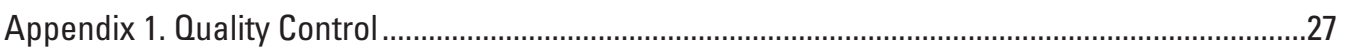

Appendix 2. Alternative Depreciation System Methods ...............................................................29

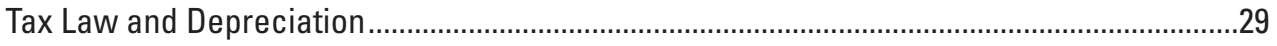

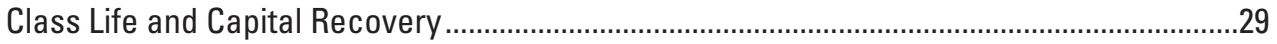

Straight Line Depreciation ...........................................................................................

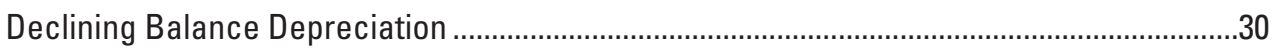

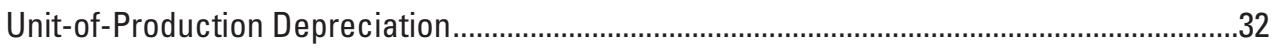

Lump-Sum Depreciation (Expensing) .......................................................................................3

\section{Figures}

1. Timeline showing the life-of-mine cost structure ...........................................................

2. Timeline showing net present value calculations during different

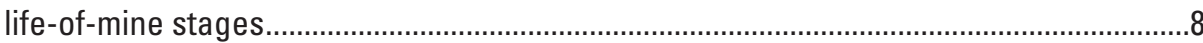

3. Diagram showing a breakdown of the costs considered in economic

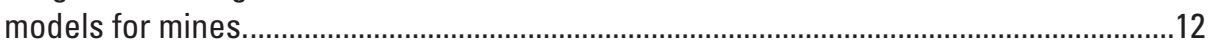

4. Project timeline showing principal mining functions ...................................................12

5. Diagram showing the relationship between uncertainty and knowledge at different stages as knowledge of the mining operation expands ....................................18

6. Diagram showing the relationship between the accuracy of cost estimates and the degree of project definition for different classes of cost estimates ...................19

7. Graph showing surface coal mine reserve estimates....................................................21

\section{Tables}

1. Generic cost estimate classification system and suggested contingencies....................2

2. Submodels supporting surface and underground mine models ......................................

3. Calculation method for after-tax cash flow.................................................................

4. Calculations of simple and compound interest .............................................................

5. Nomenclature for economic calculations (modified from Stermole, 1974) ........................7

6. Calculation of net present value (NPV) for two projects with equal project lives ............9

7. Calculation of net present value (NPV) for two projects of unequal duration ..................9

8. Example of comparative interest rates on project costs ...............................................10

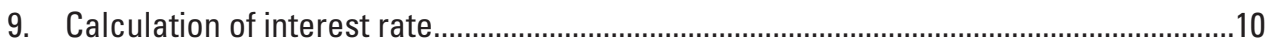

10. Thirty-year U.S. Department of the Treasury note interest and inflation rates................10

11. Calculation of six-tenths rule for cost escalation .......................................................11

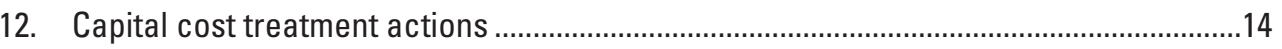

13. Key mining inputs in U.S. Geological Survey coal assessments ...................................17

14. Calculation of breakeven price per ton (modified from Stermole, 1974) ..........................20

1.1. Selection of practices recommended by AACE International for

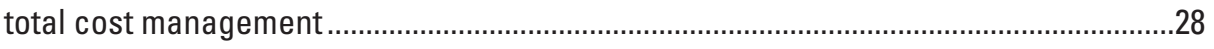

1.2. Internal Revenue Service (IRS) business guidelines..................................................28

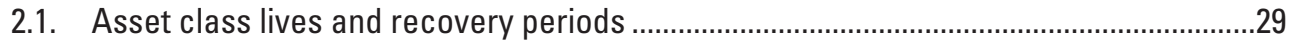


2.2. Suggested service life of equipment ........................................................................

2.3. General depreciation system for depreciable mining …...............................................

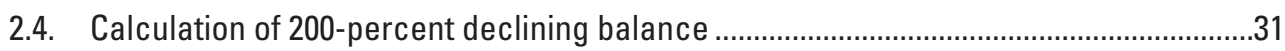

2.5. Calculation of comparative accelerated and straight line depreciation..........................32

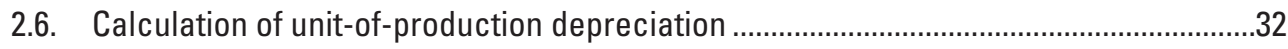

2.7. Calculation of lump-sum (expensing) depreciation .......................................................33

2.8. Calculation combining expensing with accelerated and straight

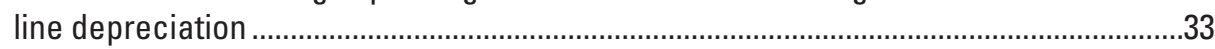

\section{Conversion Factors}

U.S. customary units to International System of Units

\begin{tabular}{lcl}
\hline \multicolumn{1}{c}{ Multiply } & By & \multicolumn{1}{c}{ To obtain } \\
\hline foot $(\mathrm{ft})$ & Length & meter $(\mathrm{m})$ \\
\hline & 0.3048 & \\
\hline cubic yard ( $\left.\mathrm{yd}^{3 \text { or cyd }}\right)$ & Volume & cubic meter $\left(\mathrm{m}^{3}\right)$ \\
\hline & 0.7646 & \\
\hline pound, avoirdupois $(\mathrm{lb})$ & Mass & kilogram $(\mathrm{kg})$ \\
ton, short $(2,000 \mathrm{lb})$ & 0.4536 & metric ton $(\mathrm{t})$ \\
\hline
\end{tabular}

\section{Abbreviations}

AACE

ADS

Btu/lb

CPI

DCFROR

DOE

GDS

IRS

MACRS

NPV

PPI

ROI

ROR

USGS

U.S. Treasury

Year 0

Year $n$

Year $n+k$
AACE International

alternative depreciation system

British thermal unit per pound

Consumer Price Index

discounted cash flow rate of return

U.S. Department of Energy

general depreciation system

Internal Revenue Service

modified accelerated cost recovery system

net present value

Producer Price Index

return-on-investment

rate-of-return

U.S. Geological Survey

U.S. Department of the Treasury

initial project year

any year of a project schedule and may coincide with Year 0

any year following a Year $n$ and may coincide with end year for project 



\title{
Economic Analysis for U.S. Geological Survey Coal Basin Assessments
}

\author{
By Paul E. Pierce
}

\section{Abstract}

This report presents economic principles and applications as they pertain to the U.S. Geological Survey's U.S. Coal Resources and Reserves Assessment Project. This report compares commercial and governmental applications of economic principles and evaluation techniques. Common practices are described for evaluating the commercial investment potential of coal properties and calculating the government reserve potential of major U.S. coal basins. This report discusses economic principles that are applicable to typical mining feasibility studies as well as those categories and cost items that are often misused.

\section{Introduction ${ }^{1}$}

The U.S. Geological Survey (USGS) performs the public service of designating national coal reserves as a function of its U.S. Coal Resources and Reserves Assessment Project. Coal reserves are resources that can be profitably recovered and are distinguished from those resources that can be physically, but not profitably, recovered. Economic analysis is the tool for distinguishing between profitable coal reserves and nonprofitable coal resources.

Economic analysis of mining operations is a special application of microeconomic theory that has long been espoused by commercial and government entities as the only practical means of (1) determining the advisability of advancing natural resources recovery, (2) detailing unit operations necessary to conduct mining, and (3) calculating profitability potential. Economic analysis provides a means for scoping, decision making, and budgeting for commercial and government interests alike.

A USGS coal assessment is a collaborative team process that integrates geological characterization, coal bed correlation, social infrastructure evaluation, mining feasibility, and economic analysis. Geological and mining modeling are coordinated to provide representative resource recovery that can be applied to both a few thousand acres and hundreds of square miles of basinwide coal deposits.

This report has a dual purpose: (1) a primer of how to perform economic studies of mining operations and (2) an explanation of how USGS coal assessments are conducted.

\footnotetext{
${ }^{1}$ Terms that are defined in the Glossary are given in boldface type at their first use in the report.
}

A framework of standards and sound practice as provided by well-recognized authoritative sources supports the guidance provided in this report.

This report is organized into four primary sections as follows:

- The "Coal Resources, Mining Methods, and Modeling" section discusses parameter modeling.

- The "Money Value Concepts" section explains what money is and how it is affected by time.

- The "Cost Estimating Components" section reviews the best practices of costing.

- The "U.S. Geological Survey Evaluation Approach" section describes the method of economic analysis based on the time value of money.

The principles and methods described in this report are meant to apply solely to USGS coal assessments. However, use for noncoal mineral assessments may be considered with some modifications.

\section{Coal Resources, Mining Methods, and Modeling}

A USGS coal reserve/resource assessment includes mine models that are representative of all potential mining methods and configurations of operation in a coal field or coal basin. A mine model of unspecified arrangement and extent usually covers only a few thousand acres as defined by an economic life-of-mine duration. However, this USGS economic reserve/ resource approach is designed to fit the statistical average of geological conditions extending over several hundred square miles. USGS mine models include any reasonable surface and underground mining methodology consisting of coordinated activities that are common to normal mining engineering practices. Optimization of mining systems is not attempted as site-specific conditions are undefined and optimization is not appropriate for wide-area application. The conceptual design evaluation for coal bed recovery is usually conducted for highly mechanized methodologies that provide near consistency and uniformity during mining operations. These methods are sized to provide maximum annual production and the most favorable mine economics. 


\section{Geological Modeling}

Average coal characteristics are determined from correlating coal deposits over large areas. Coal deposits are generally broad, continuous sheets that may extend over several hundred square miles. The overlying and separating noncoal intervals are also characterized as broad sheets. The characteristics of these sheets are incorporated into a geological model that provides a profile, which is a stratigraphic representation of the thickness of coal and noncoal layers. The vertical dimension of each layer will usually be equal to the thickness of that layer. For inclined coal beds, the vertical dimension of the profile is an apparent thickness of the layer, which is converted in mining evaluations to true thickness. As an example, a uniform 10-feet thick coal bed that is inclined 30 degrees from horizontal will have a vertical apparent thickness of 11.5 feet.

Except for the coal beds, the strata in the geological model are undifferentiated and largely unspecified. Coal beds are designated as lignite, subbituminous, bituminous, or anthracite. Noncoal is designated as a layering of unspecified sedimentary rock. Coal bed discontinuities, such as sand channels, lenticular deposition, and burn zones, are seldom characterized unless they substantially affect the uniformity of a geological model.

Additional information may be incorporated into the geologic model, including coal quality data from drill holes. Heating value is one measure of coal quality that is used to determine the market price of the coal being evaluated. Average values for density and other properties are usually based on analogs for coal and noncoal layers.

\section{Mine Models}

Actual mine designs and USGS mine models are essentially the same initially. Both are based on engineering studies that determine the costs associated with mining. A mine model for an actual mine is a decision-making tool that is used to determine the advantages and disadvantages of conducting a commercial venture. A USGS mine model uses the conditions for an actual mine but extends these conditions over an entire coalfield or basin.

USGS mine models may incorporate a comparable degree of economic information used for an actual mine venture up to and including a Class 4 estimate from AACE International (AACE) (see table 1 and appendix 1). A USGS mine model generalizes as much as possible to include the greater uncertainty and lack of detail associated with broad land expanses, but an actual mine design is prepared for site-specific locations. USGS cost estimates that arise from the model often have much less information or ignore certain details that are not representative of the average conditions for a wide area. However, both commercial and USGS cost estimates use methodologies and levels of technology that were used historically and are currently in practice throughout the United States.

\section{Commercial Mining Economic Studies}

Preoperational evaluations for corporate mining investments are often conducted in a phased approach that involve multiple evaluations over time. Each subsequent evaluation is performed with a better understanding of mining conditions and expenses and an increasing amount of available information from which

Table 1. Generic cost estimate classification system and suggested contingencies.

[AACE, AACE International; \%, percent]

\begin{tabular}{|c|c|c|c|c|c|}
\hline \multicolumn{3}{|c|}{ General cost estimate classification system ${ }^{1}$} & \multicolumn{3}{|c|}{ Suggested contingency } \\
\hline $\begin{array}{l}\text { AACE estimate } \\
\text { class }\end{array}$ & Project stage & Expected accuracy range ${ }^{2}$ & $\begin{array}{c}\text { Contingency for all } \\
\text { projects }^{3}\end{array}$ & $\begin{array}{c}\text { Well-known } \\
\text { projects }^{4}\end{array}$ & Uncertain projects ${ }^{4}$ \\
\hline 4 & Feasibility & $\begin{array}{l}\text { Low: }-15 \text { to }-30 \% \\
\text { High: }+20 \text { to }+50 \%\end{array}$ & $30 \%$ & $25 \%$ & $40 \%$ \\
\hline 2 & Bid tender & $\begin{array}{l}\text { Low: }-5 \text { to }-15 \% \\
\text { High: }+5 \text { to }+20\end{array}$ & $15 \%$ & $10 \%$ & $20 \%$ \\
\hline 1 & Check estimate & $\begin{array}{l}\text { Low: }-3 \text { to }-10 \% \\
\text { High: }+3 \text { to }+15 \%\end{array}$ & $5 \%$ & $5 \%$ & $10 \%$ \\
\hline
\end{tabular}

'Karlsen and Lereim, 2005 and Bredehoeft, Dysert, and Pickett, 2019.

${ }^{2}$ Bredehoeft, Dysert, and Hollmann, 2019.

${ }^{3}$ Rothwell, 2005.

${ }^{4}$ Karlsen and Lereim, 2005. 
a more detailed design can be produced. The knowledge of corporate financial expectations is ideally increased with this methodology, although when financial feasibility is badly skewed (see the "Costing Risk Mitigation in Economic Evaluations" section), potential profitability is endangered. A phased approach gradually increases the accuracy of cost estimates. Greater knowledge is assumed to correlate with lesser risk in achieving the project goals.

\section{U.S. Geological Survey Mining Economic Studies}

USGS coal assessments strive for estimate reliability by adhering to AACE recommended procedures and Internal Revenue Service (IRS) guidelines as identified in tables 1.1 and 1.2 in appendix 1. Mining economic studies for USGS coal assessments lie within the range between "Concept Screening" and "Feasibility" (see table 1). An order-of-magnitude estimate, concept screening, or feasibility study as defined by AACE may extend across Class 4- and 5-estimate levels. When preparing an order-of-magnitude estimate, an estimator has only a small amount of project knowledge, which might range from 5 to 10 percent of what needs to be defined. Heavy reliance is then placed on the estimator's experience. The accuracy in the costs can range from -30 percent to +100 percent of calculated cost. To mitigate the risk of not achieving the calculated cost target, a cost contingency will add 30 to 50 percent to the cost of the project (for example, a cost contingency would add between $\$ 30$ million and $\$ 50$ million to a $\$ 100$ million estimate). Negative cost contingencies do not exist. Either a Class 4- or Class 5-related contingency is selected based on the level of design detail, which is tied to geological correlations, social conditions, and other pertinent information. The amount of detail available is never sufficient to allow AACE Class 3, 2, and 1 estimates to be applied to coal field or basinwide conditions in USGS coal assessments.
An important concept should be realized. An order-of-magnitude estimate with +30 to +50 percent contingency performed for an actual mining venture 4 years before operations commence ideally should have project costs that are nearly equivalent to a definitive cost estimate or Class 1 estimate with a +5 to +15 percent contingency performed months before mining commences if the estimates are performed correctly. Each succeeding estimate up to and extending beyond real mine startup should slightly correct uncertainties and market force changes to produce average estimate values. The USGS model attempts to achieve similar accuracy.

Single and multiple coal bed mining evaluations are performed by developing conceptual surface or underground mine model designs as appropriate. The mine models evaluate and provide cost estimates of equipment, facilities, personnel, supplies, and utilities. Additionally, the mine models provide a discounted cash flow rate of return (DCFROR) basis for determining coal reserves. Supporting submodels are developed for conducting more detailed and complex calculations and correlations. Submodels are described in table 2 and provide a means of calculating default input values for the master models without further complicating the master models.

Mine models for surface mines identify each coal bed and noncoal layer as distinct units requiring the four primary operations of topsoil removal, blasting, loading, and haulage. By using a "layer cake" analog for horizontal beds, noncoal and coal beds are removed one layer or tier at a time moving downward to the lowest producing bed. The recovery of each layer is dependent upon the recovery rate of previous strata, which establishes the coal production rate. The amount of material to be removed on a volumetric basis is likely to vary from layer to layer. Therefore, each unit may use different equipment. Underground mining is conducted within certain coal beds without disturbing the burden except for the construction of single ramps and shafts that are needed to access the mine, remove coal, and ventilate the underground workings.

Table 2. Submodels supporting surface and underground mine models.

\begin{tabular}{lc}
\hline \multicolumn{1}{c}{ Submodel } & Description \\
\hline Coal handling & Interactive mass balance flowsheets, equipment and facility design and \\
performance, component costing & Earthwork and design components and costing \\
Land improvement & Mine electrical loads, substation design, emergency power generation, \\
Mine electrical & component costing \\
Mine plant & Building design and costing; equipment costing - office, emergency, laboratory, \\
& plant stationary; administration and labor personnel costing \\
Shaft, ramp, and underground construction & Shafts, ramps, hoisting construction and components design and costing \\
Ventilation & Surface and underground fans, ducting, foundations, housings, and installation \\
& design and costing \\
Exploration & Estimated number of drill holes and drilling costs \\
Coal preparation plant & Process flowsheets and component design and costing \\
\hline
\end{tabular}




\section{Money Value Concepts}

Money is the circulating medium of exchange allowing individuals and groups to participate in the U.S. economy. Money can be identified as currency and various negotiable monetary instruments that, when coupled with public support, achieves a value. Liquidity is an important aspect of monetary value and becomes pertinent depending upon how money is used or evaluated. The worth of a U.S. dollar is the purchasing power it has in acquiring assets. This worth can be highly flexible depending on its underlying monetary basis, how the dollar is manipulated in financial applications, and the point in time that it is applied. This section presents monetary concepts and how they apply to USGS coal assessments.

\section{Economic and Financial Analyses}

The terms "economic analysis" and "financial analysis" are often used synonymously, but that is incorrect. Their differences are summarized in the following definitions.

- Economic analysis.-The purpose of economic analysis is to evaluate the relative merits of investment situations from a profit and cost basis by relating to the profitability of a proposed project.

- Financial analysis.-The purpose of financial analysis is to determine how a project will be funded. Common funding sources include leveraging through borrowing from personal and corporate funds, funding through debt offerings (bonds), and common stock offerings.

Economic analysis in USGS coal assessments has the sole purpose of developing a "zero point," which is an indicator of profitability that determines the point above which profit may be realized and below which a loss occurs. The zero point is the breakeven cost where the expenditure per unit mass weight (tonnage in 2,000-pound lots, or short tons) equals the coal price per weight. Calculation of the breakeven cost is discussed in the "Breakeven Evaluation" section.

Financial techniques, such as price hedging and leveraging, can provide capital protection or profit enhancement. However, these techniques have little direct effect on determining coal reserves; therefore, USGS coal assessments do not incorporate financial analysis.

\section{Cash Flow in Mine Economics}

Cash flow is the difference between income and operating cost. Income is derived from selling coal at a unit price (in dollars per ton). Positive cash flow occurs when income is greater than cost. The flow of cash occurs throughout a production period as revenues are generated and the costs of income generation are incurred. Revenues (income) and costs occur throughout the life of a mining project and are often evaluated as a series of annual events. Annual cash flow in mining usually varies; however, in commercial feasibility evaluations and USGS coal assessments, annual cash flows are assumed to be uniform unless other information is available.

Cash flow is calculated on an after-tax basis for any annual period in which income and costs occur. Cash flow usually occurs during the production phase of a mining project, which follows the end of the initial capital investment and lasts until a final point in the life of the mine; during the production phase, capital costs are incurred to complete the mining project. Certain income, such as that generated by the return of a posted reclamation bond or salvage of equipment, may be taken in during the final period of operation, but this income is merely the return of previously expended investments. In financial analyses, cash flow can be further adjusted by recovering the investment costs. The balance (cash flow less investment cost) can be applied to stockholder payments or retained as earnings for a corporation. However, as financial analysis is not incorporated into USGS coal assessments, cash flow is not adjusted in economic evaluations but is equated to investment recovery.

A sample calculation of how cash flow is determined after several deductions to the income is shown in table 3 . This calculation is performed for each income-producing year, usually during a period that corresponds with production or mining of coal starting with the first year (Year $n$ ) and continuing to a final year (Year $n+k$ ). USGS assessments usually perform this calculation without any breaks or pauses in production.

\section{Time Value of Money and Timeline Cost Scheduling}

Economic analysis in USGS coal assessments is based on the concept that money today is worth more than an equal amount in the future. Changing monetary value with time is referred to as "time value of money." USGS coal assessments assume that a constant decrease in monetary value occurs due to inflation. Deflation alters this process and adds value. However, historic deflationary periods have been few and brief with the norm being some inflationary increase in value from year to year.

In USGS coal assessments, economic analyses are viewed from a present value standpoint where expenditures that will be made in the future are devalued in relationship to their present value. A deterministic evaluation is favored; in this evaluation, parametric values are defined based upon specific conditions and the calculated results are directly tied to inputs. A stochastic evaluation represents a relativistic viewpoint that applies randomness and uses statistical 
distributions to determine a likely outcome from nonanalytical manipulation of variables. The accuracy of an evaluation based on statistical inference will not be immediately apparent and should be assumed to have a higher contingency applied to final cost than in a deterministic evaluation. Either approach is valid. The amount and quality of design detail largely indicates which approach should be used in USGS coal assessments. Cost estimates are based on project timelines whether they are explicitly shown or not. A mining operation may have scheduled disruptions or idle times that affect its economic outcome, but a USGS coal assessment assumes continuous activity from start to finish. An exception is offered in the "Unit-of-Production Depreciation" section in appendix 2.
The timeline shown in figure 1 includes costs throughout the life of the mine from inception to decommissioning. Points in time are represented symbolically with variables " $n$ " and " $k$." The variable " $n$ " can represent any year on a timescale; $n=0$ is shown in figure 1 as project startup. The variable " $k$ " represents some year after project startup. The starting point with any economic evaluation for a USGS coal assessment occurs at Year 0. A simplified economic evaluation may be conducted in which all preproduction costs are brought forward to Year 0 and all capital expenses will each have a present value. Project time scales are often projected for 20-year durations. Shorter and longer project lives may be used as appropriate. The longest model timeframes extend to a 40-year life.

Table 3. Calculation method for after-tax cash flow.

[Year $n$, initial project year; Year $n+k$, end year for project]

\begin{tabular}{|c|c|c|c|}
\hline Year $n$ & Year $n+1$ & Year $n+2 \ldots$ & Year $n+k$ \\
\hline \multicolumn{4}{|l|}{ Income } \\
\hline \multicolumn{4}{|l|}{ - Royalties } \\
\hline \multicolumn{4}{|l|}{ - Operating cost } \\
\hline \multicolumn{4}{|l|}{ - Depreciation } \\
\hline \multicolumn{4}{|l|}{$=$ Taxable income } \\
\hline \multicolumn{4}{|l|}{ - Taxes } \\
\hline \multicolumn{4}{|l|}{$=$ Net profit } \\
\hline \multicolumn{4}{|l|}{ + Depreciation } \\
\hline$=$ Cash flow & & & \\
\hline
\end{tabular}

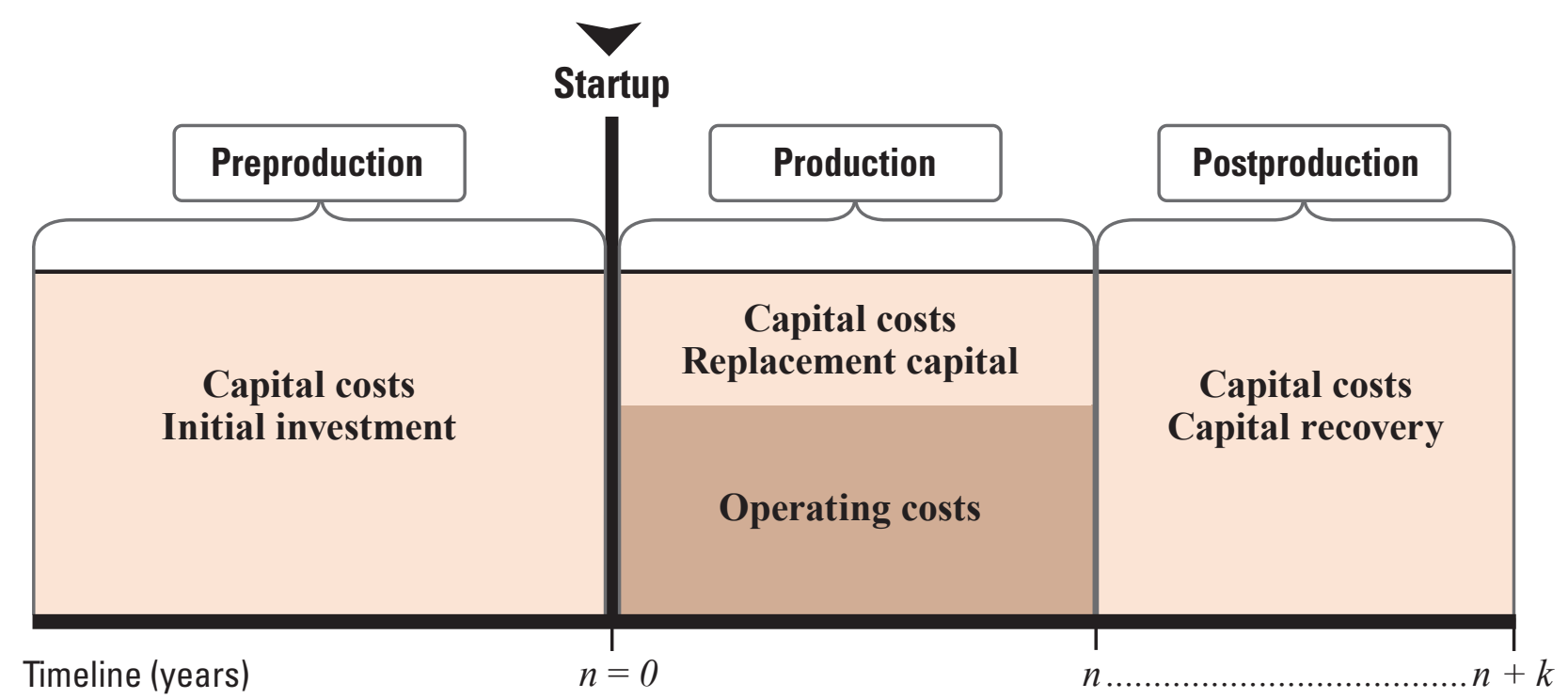

Figure 1. Timeline showing the life-of-mine cost structure. ( $n$, any year on a timescale; $k$, some year after project startup) 


\section{Discounted Cash Flow and Net Present Value Analyses}

\section{Interest Rate}

The rate of interest " $i$ " is the nominal interest as described in the "Determining Rates of Interest" section. Rate is the constant percentage increase or decrease in interest over the term of economic evaluation. Often, calculations are conducted for several interest rates to observe the effects of changing interest rates on economic outcomes. Coal resource breakeven calculations that determine reserve tonnage at 6 percent may be significantly different than a breakeven calculation using an interest rate of 10 percent. These interest rate percentages are compounded and applied over the number of years corresponding to the length of the project.

Simple interest is add-on interest. An amount of $\$ 100$ (principle amount) invested for 1 year at 5 percent will yield $\$ 5$. If only $\$ 5$ is added the second year, the investor will earn less with simple interest than with compound interest because additional funds would have been realized through compounding. Simple add-on interest is used in certain consumer loans, credit card transactions, and bond investing situations, but is not used when investment money is involved in project funding. Therefore, USGS coal assessments do not use simple interest.

The amount of principle increases each year after the first year because the interest is added to the principle. The different mathematical relationships and the difference between simple and compound interest calculations are shown in table 4. An interest rate may be compounded monthly, quarterly, or annually for a total of 12,4 , or 1 compounding period(s) per year, respectively. Lending agencies often have a financial advantage as they may invest their securities at continuous compounding rates while paying consumers at quarterly or annual compounding rates. The interest rate is set by a lender, whether it be a bank, group of investors, or self-funding by a company, at a rate expected to provide a certain compensatory payment back to the lender or investor (return-on-investment [ROI]). All USGS coal economics are calculated for annual compounding periods, which corresponds with most industrial cost estimates.

Table 4. Calculations of simple and compound interest.

Two investments of $\$ 100$ each are made. One earns compound interest (compounded annually) and the other earns simple interest. Both investments are left alone for 10 years. An annual interest rate of 5 percent is applied to both. Compounding annually earns $\$ 12.89$ more than simple interest.

\begin{tabular}{ll}
\hline Investment & $\$ 100.00$ \\
Interest rate & 5 percent annually \\
Period & 10 years \\
Compound interest & $\$ 100 \times(1+0.05)^{10}=\$ 162.89$ \\
Simple interest & $\$ 100+(0.05 \times \$ 100 \times 10)=$ \\
& $\$ 150.00$ \\
\hline
\end{tabular}

All mining economic evaluations are performed to determine whether a positive ROI is possible. The rate-ofreturn (ROR) is the fixed price of money that is charged for an investment and ROI is the U.S. dollar amount that a lender can expect to be paid back on an investment at an established ROR. If a $\$ 100$ million investment returns $\$ 100$ million, then the investment has zero advantage and the ROI and the ROR are zero. A \$100 million investment that returns \$105 million after 1 year and $\$ 162.9$ million after 10 years has a 5 percent annual percentage growth or 5 percent ROR.

\section{Commercial Mine Economic Analysis}

An estimator for a future commercial mine project may have two sets of known values from which to calculate a DCFROR: (1) the revenue stream for a projected production rate and (2) a schedule of market prices (that is, tons per year at dollars per ton). A calculation is performed using the method shown in table 3 . All the resulting annual cash flows are then discounted to present value. The total of discounted cash flows is set equal to the sum of all discounted capital costs. The discount or interest rate that satisfies equations 1 and 2 is the DCFROR. Usually, the mining company or investment group has an expected ROI rate that is compared with the DCFROR to determine if the project should proceed.

\section{U.S. Geological Survey Economic Analysis}

When conducting coal assessments, USGS uses net present value (NPV) analysis to determine a breakeven pricecost relationship as discussed in the "Breakeven Evaluation" section. NPV analysis is a common economic tool used to evaluate capital investments in general activities and in USGS coal assessments. NPV calculations provide an indicator of potential profit or loss. A positive NPV indicates profitability, a negative value represents loss, and a value of zero means that revenues and costs are equal. The procedure for conducting NPV calculations has been set forth in "Economic Evaluation and Investment Decision Methods" (Stermole, 1974). An abbreviated form of an NPV calculation uses the notation shown in table 5 .

\section{Net Present Value Nomenclature and Calculation}

The notation " $P / F_{i, n}$ " is a convenient expression for the present value, $P$, of a future expense, $F$, with the subscripts " $i$ " and " $n$ " for interest rate and year of expense, respectively. In a calculation that provides the NPV of annual cash flows, capital investment, and salvage, as shown in equation 1 (Stermole, 1974), a string of cash flows for any amounts are expressed as $C F_{1}, C F_{2}, \ldots C F_{n}$ where $C F_{1}$ and $C F_{2}$ are the first two cash flows and $C F_{n}$ is the final year of cash flow, which usually coincides with the end of the project. Total capital investment is expressed as $C$, which includes all the investment expended for a project. Capital may be returned in the form of salvage, 
which is expressed as $L$. Original capital is expensed in Year 0 (present time) and is not discounted. Subsequent capital infusion, cash flows, and salvage are discounted to present value.

$$
\begin{gathered}
N P V=0=C F_{1}\left(P / F_{i, 1}\right)+C F_{2}\left(P / F_{i, 2}\right)+\ldots+ \\
C F_{n}\left(P / F_{i, n}\right)-C+L\left(P / F_{i, n}\right) .
\end{gathered}
$$

Cash flow may be different each year as shown in equation 1 . The interest rate, $i$, is the primary unknown in the equation and is calculated through trial and error until NPV equals zero. Interest rates determined through this calculation may differ from those discussed later. This calculation provides interest rates when investment, cost, and revenue amounts are known for the purpose of showing that the total capital investments must equal the discounted cash flow as shown in equations 3 and 4 . Should cash flow be consistent or uniform each year, the $P / F_{i, n}$ factor is replaced with $P / A_{i, n}$ where $A$ represents a uniform annual value. The relationship is altered as shown in equation 2 to provide the NPV of uniform annual cash flows, capital investment, and salvage:

$$
N P V=0=C F\left(P / A_{i, n}\right)-C+L\left(P / F_{i, n}\right),
$$

where

$$
\begin{aligned}
& P / A_{i, n} \quad \begin{array}{c}
\text { present value of uniform cash flows for each } \\
\text { year of the project life. }
\end{array}
\end{aligned}
$$

Salvage may be dropped from consideration if it does not appreciably affect the outcome of the calculation over a long project life. Then, the NPV equation can be rewritten as equation 3 where capital cost, $C$, equals the discounted cash flow, $C F$ :

$$
C=C F\left(P / A_{i, n}\right) .
$$

Equation 3 shows the relationship between capital investment and uniform cash flow and is, thus, representative of several economic applications. However, equation 3 does not include subsequent capital investments that coincide with some cash flow during the production phase. These capital infusions may include one-time and recurring expenditures that typically occur every $3,5,7,10,14$, and 15 years for a 20 -year project life $\left(C_{3}, C_{5}, C_{7}, C_{10}, C_{14}, C_{15}\right)$. Each is discounted to present value and may be expressed as $C_{n}\left(P / F_{i, n}\right)$ where $n=3,5,7,10$, 14, and 15. Then, the total capital expense, $C$, is sum of the original capital investment, $\mathrm{C}_{0}$, and subsequent capital infusions so that equation 3 can be rewritten to show the relationship between initial and subsequent capital investments and uniform cash flow, $C F$, as in equation 4 :

$$
C=C_{0}+C_{n}\left(P / F_{i, n}\right)=C F\left(P / A_{i, n}\right) .
$$

The single payment compound amount factor, $F / P_{i, n}$, which is the reciprocal of $P / F_{i, n}$, is used to adjust preproduction costs to the present, Year 0 . When to apply these relationships $\left(P / F_{i, n} ; F / P_{i, n}\right.$; and $\left.P / A_{i, n}\right)$ is shown on the cost structure timeline in figure 2 .

\section{Effect of Life-of-Mine Duration on Net Present Value}

Most USGS coal assessments are conducted for 10-, 15-, $20-$, or 30-year nominal mine lives. Life-of-mine duration is largely based on mining analogs for the region being assessed. Most assessments use a 20-year production period. Among several other considerations, production evaluations at 20 years tend to (1) show enhanced returns on investment, (2) optimize machinery owner and operating costs, and (3) more efficiently use capital assets. However, shorter and longer durations may be appropriate. The length of the production phase (cash flow producing period) can affect comparative NPV calculations as shown in tables 6 and 7.

Two projects, $\mathrm{A}$ and $\mathrm{B}$, are compared in tables 6 and 7 . Each project is evaluated at a 5 percent interest rate. NPV is calculated for a 20 -year life in table 6 for both projects. Project $\mathrm{B}$ has a slightly higher capital investment and realizes a higher annual income. Both projects are acceptable because their positive NPVs indicate satisfactory investments. Based on these calculations, Project B is the better economic investment because of the higher NPV. The increased value in Project B

Table 5. Nomenclature for economic calculations (modified from Stermole, 1974).

\begin{tabular}{ll}
\hline \multicolumn{1}{c}{ Symbol } & \multicolumn{1}{c}{ Description } \\
\hline$P$ & Present; current point in time \\
$F$ & Future; a subsequent point in time \\
$A$ & Annual; series of yearly periods \\
$C$ & Capital; also investment \\
$C F$ & Cash flow; income-cost \\
$i$ & Interest rate \\
$L$ & Salvage \\
$n$ & Compounding period, year \\
$P / A$ & Uniform series present amount factor; present \\
& value of uniform annual costs/income \\
& $\quad P / A_{\mathrm{i}, \mathrm{n}}=\frac{(1=i)^{n}-1}{i(1=i)^{n}}$
\end{tabular}

P/F $\quad$ Single payment present amount factor; present value of a future dollar amount

$$
P / F_{\mathrm{i}, \mathrm{n}}=\frac{1}{(1=i)^{n}}
$$

F/P Single payment compound amount factor; future value of a present dollar amount

$$
F / P_{\mathrm{i}, \mathrm{n}}=(1=i)^{n}
$$


lies in the larger cash flow, which could be the result of lower operating costs. When Project B is compared with Project A for different project durations in table 7, Project B is still the better option. However, if the life of Project A is increased from 10 to 20 years and Project B's life is decreased from 20 to 10 years, Project A has an NPV $=\$ 203$ million and Project $\mathrm{B}$ has an NPV $=\$ 174$ million, so Project A is the better investment. Generally, longer project lives improve mine economic outcomes, as long as rated tonnage remains the same or increases and the cost of mining does not increase. This means that replacement cost has a lesser effect than the amount of tonnage mined over time.

Further analyses show that costs and revenues that occur within the first 5-10 years of project life have greater economic impact than those occurring in 10-15 years because of the time value of money. Projects tend to be detrimentally affected by shortening the project life.

\section{Escalated Dollar Evaluations}

USGS coal assessments are conducted with escalated dollar values. Escalation is the increase in the cost of assets that results from inflation, supply and demand, and other factors. Escalated dollar values are calculated for current dollars that have different purchasing powers at different points in the future. USGS mine models contain many dissimilar items (for example, steel, electricity, chemicals, explosives, labor) that change in value at different rates each year. Two key parameters that are used in calculating the time value are the interest rate and duration.

\section{Determining Rates of Interest}

The interest rate must be known for time value of money calculations, especially for USGS coal assessments. Variations by a few percentage points substantially affect economic outcomes. As shown in table 8 , a 2 percent interest rate increase could cost a mining project more than $\$ 100$ million and a 4 percent increase could cost an additional \$258 million. An interest rate of 8 percent for USGS coal assessments was used from 2008 through 2013. A lower rate of 6 percent was calculated in a 2014 internal USGS estimate. USGS coal assessments used an interest rate of 4 percent from 2016 to 2018 based on calculations that include an interest base rate, inflation, and uncertainty (if known), as shown in table 9. This lower rate is largely due to the state of the U.S. economy beginning in the last quarter of 2016. The volatility of the economy could cause money values to rise or fall, so frequent reevaluations of interest rates are performed.

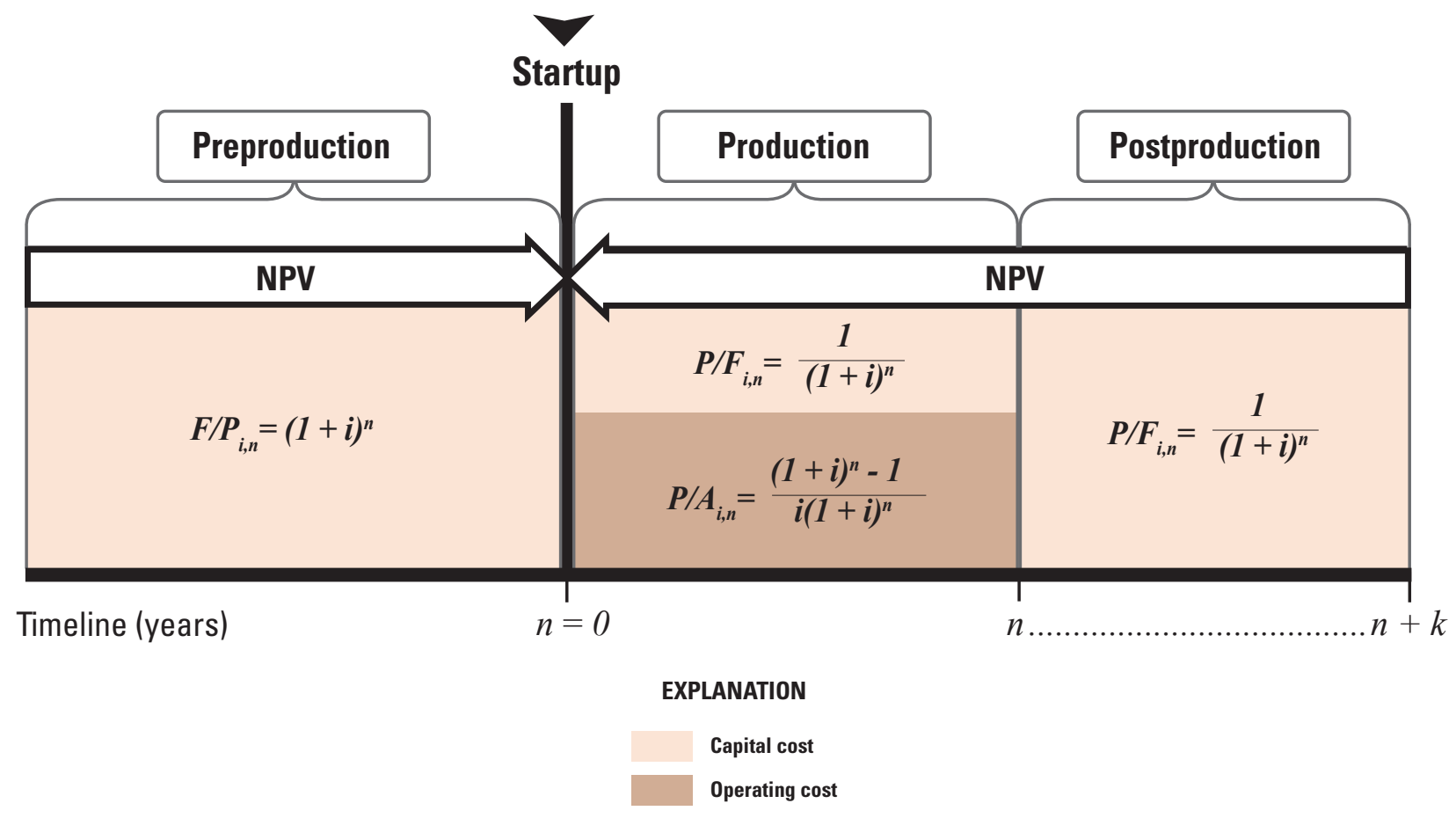

Figure 2. Timeline showing net present value (NPV) calculations during different life-of-mine stages. ( $\boldsymbol{F} / \boldsymbol{P}_{\mathrm{i}, n^{\prime}}$ future single amount from a single present amount; $i$, rate-of- return, interest; $n$, number of interest compounding periods; $\boldsymbol{P} / \boldsymbol{F}_{i, n^{n}}$, present single amount from a single present amount; $\boldsymbol{P} / \boldsymbol{A}_{\mathrm{i}, \mathrm{n}^{\prime}}$ present compound amount from a single future amount) 
Table 6. Calculation of net present value (NPV) for two projects with equal project lives.

$[P / A$, present value of uniform cash flows; $P / F$, present value of a future expense $]$

\begin{tabular}{|c|c|c|}
\hline & Project A & Project B \\
\hline Project life $(n)$ & 20 years & 20 years \\
\hline Capital cost $(C)$ & $\$ 50$ million & $\$ 65$ million \\
\hline Salvage $(L)$ & $\$ 10$ million & $\$ 12$ million \\
\hline Interest rate $(i)$ & 5 percent & 5 percent \\
\hline NPV calculations & $\begin{array}{l}N P V=\text { annual income }+ \text { salvage }- \text { capital } \\
\begin{aligned} N P V & =\left(\$ 20 \text { million } \times P / A_{5,20}\right)+(\$ 10 \text { million } \\
& \left.\times P / F_{5,20}\right)-\$ 50 \text { million } \\
& =(20 \times 12.462)+(10 \times 0.3769)-50 \\
& =249+4-50=203\end{aligned}\end{array}$ & $\begin{array}{l}N P V=\text { annual income }+ \text { salvage }- \text { capital } \\
\begin{aligned} N P V & =\left(\$ 250 \text { million } \times P / A_{5,20}\right)+(\$ 12 \text { mil- } \\
\left.\text { lion } \times P / F_{5,20}\right)-\$ 65 \text { million } & =(30 \times 12.462)+(12 \times 0.3769)-65 \\
& =374+5-65=314\end{aligned}\end{array}$ \\
\hline
\end{tabular}

Table 7. Calculation of net present value (NPV) for two projects of unequal duration.

$[P / A$, present value of uniform cash flows; $P / F$, present value of a future expense $]$

\begin{tabular}{|c|c|c|}
\hline & Project A & Project B \\
\hline Project life $(n)$ & 10 years & 30 years \\
\hline Capital cost $(C)$ & $\$ 50$ million & $\$ 65$ million \\
\hline Salvage $(L)$ & $\$ 10$ million & $\$ 12$ million \\
\hline Interest rate $(i)$ & 5 percent & 5 percent \\
\hline NPV calculations & $\begin{array}{l}N P V=\text { annual income }+ \text { salvage }- \text { capital } \\
\begin{aligned} N P V & =\left(\$ 20 \text { million } \times P / A_{5,10}\right)+(\$ 10 \text { million } \\
& \left.\times P / F_{5,10}\right)-\$ 50 \text { million } \\
& =(20 \times 7.722)+(10 \times 0.6139)-50 \\
& =154+6-50=110\end{aligned}\end{array}$ & $\begin{array}{l}N P V=\text { annual income }+ \text { salvage }- \text { capital } \\
\begin{aligned} N P V & =\left(\$ 30 \text { million } \times P / A_{5,30}\right)+(\$ 12 \text { million } \\
& \times \begin{array}{r}\left.P / F_{5,30}\right)-\$ 65 \text { million } \\
\end{array} \quad(30 \times 15.372)+(12 \times 0.2314)-65 \\
& =461+3-65=399\end{aligned}\end{array}$ \\
\hline
\end{tabular}


Published interest rates are nominal interest rates. The real interest rate is determined by subtracting inflation, as demonstrated in the simplified version of the Fisher equation (Cooper and John, 2012) shown in equation 5. Inflation is measured as a general increase in the overall price of goods and services in the U.S. economy. Inflation varies from one metric to another, such as the Consumer Price Index (CPI), gross domestic product, money supply, and U.S. Department of the Treasury (U.S. Treasury) securities. U.S. Treasury securities may provide the mining industry with the clearest guidance on projecting reliable interest rates.

$$
r=n-i
$$

where:

$$
n=(1+i) \times(1+r)-1 \text {, }
$$

where

$\begin{array}{ll}n & \text { is the nominal interest rate, } \\ i & \text { is the inflation rate, and } \\ r & \text { is the real interest rate. }\end{array}$

The annual average CPI inflation equation (Coinnews Media Group LLC, 2019) is shown in equation 6.

$$
I=\left(C P I_{\text {year } 2}-C P I_{\text {year } 1}\right) \div C P I_{\text {year } 1}
$$

where

$$
\text { CPI is the CPI annual average. }
$$

\begin{tabular}{|c|c|c|c|}
\hline \multicolumn{4}{|c|}{$\begin{array}{l}\text { Comparative interest rate effects on mining investment present } \\
\text { value. } \\
\text { Capital cost— } \$ 114 \text { million in Year } 0 \\
\text { Project life—-20 years } \\
\text { Interest rate—variable; } 6 \%, 8 \% \text {, and } 10 \%\end{array}$} \\
\hline & \multicolumn{3}{|c|}{ Interest rate } \\
\hline & $6 \%$ & $8 \%$ & $10 \%$ \\
\hline $\begin{array}{l}\text { Net present } \\
\text { value }\end{array}$ & \$511 million & $\$ 644$ million & $\$ 769$ million \\
\hline
\end{tabular}

Table 8. Example of comparative interest rates on project costs.

$[\%$, percent $]$

Table 9. Calculation of interest rate.

\begin{tabular}{lcl}
\hline & Rate (percent) & \multicolumn{1}{c}{ Note } \\
\hline Base interest rate & 2.57 & See table 10 \\
Inflation & 1.78 & See table 10 \\
Uncertainty & Not applicable & Not determined \\
Total & 4.00 & Rounded to nearest \\
& & whole number \\
\hline
\end{tabular}

The U.S. Treasury sells bills, notes, bonds, and inflationprotected securities to finance the national debt of the United States. All of these instruments are considered "securities" because they have unconditional backing by the U.S. Government and a low risk of defaulting. The securities are given a designation based on their durations (terms) and yields (interest rates). Except for inflation-protected securities, these securities are vulnerable to inflation and all of the securities are vulnerable to changes in interest rates.

U.S. coal mining projects tend to operate for 15-30 years. Capital borrowing for such ventures, whether from internal or external financial sources, is made for the lowest long-term interest rate available, which is comparable with 30-year rates for U.S. Treasury issues. The U.S. Federal Reserve System publishes daily constant maturity yields and real yields for 30-year securities (Ferri, 2014). Constant maturity rates on actively traded securities are adjusted daily to a rate as if issued on that day. Real yield rates are reflections of the change in purchasing power and are also known as inflationindexed rates. The difference between U.S. Treasury real yield and constant maturity yield values is the inflation rate. The midyear 2019 values of all three rates are shown in table 10 .

Inflation is a key element in forecasting future interest rates and constant discount rates of return. By necessity, future economic projections require sophisticated computer modeling that may produce a wide variance in results. There are also a variety of economic philosophies that may interpret metric relationships differently than presented in this report. Further, parametric analysis is expected to produce subtleties well beyond the realm of microeconomics that is normally evaluated for USGS coal assessments. Therefore, economic uncertainty is an indeterminate value and is discounted for assessments of future projects.

The 30-year U.S. Treasury securities rate forms the basis for a likely lending rate. Inflation is added to this value. The inflation rate is used for the cost of money in USGS coal assessments for 2018 and beyond unless otherwise adjusted.

The interest rate shown in table 9 is at a possible snapshot in time, so the interest rate will need to be reevaluated for each future year. A possible decline in the base rate with a corresponding rise in inflation, or an increase in the base rate and decrease in inflation, could offset each other and provide some stability to the calculated discount rate.

Table 10. Thirty-year U.S. Department of the Treasury note interest and inflation rates. ${ }^{1}$

\begin{tabular}{cccc}
\hline Year & $\begin{array}{c}\text { Constant maturity } \\
\text { rate }\end{array}$ & $\begin{array}{c}\text { Inflation-indexed } \\
\text { rate }\end{array}$ & Inflation rate \\
\hline 2019 & 2.57 & 0.79 & 1.78 \\
\hline
\end{tabular}

${ }^{1}$ From Board of Governors of the Federal Reserve System, 2019. 


\section{Cost-Index Projections}

Indexing is a useful tool for conducting order-of-magnitude cost estimation. An index is a dimensionless number that is derived from a ratio of cost or operating values. Indices are used to project from one point in time to another or from one size to another. Indexing escalates or deescalates a cost or price dollar value into a new value. The escalation equation shown in equation 7 is derived from the direct proportion of a new cost divided by an old cost, which equals a new index divided by an old index. The values in equation 7 can also be reversed to determine an old cost from a new cost providing the costs can be indexed in time:

$$
2017 \$=2012 \$ \times\left(\frac{2017 \text { index }}{2012 \text { index }}\right)
$$

Indices for 2012 and 2017 may be derived from several reputable sources. Indexing may be used in several ways, such as escalating current costs to future costs and converting national averages to local values. Primary sources for indexing in USGS coal assessments include

- U.S. Department of Labor Bureau of Labor Statistics' Producer Price Index (PPI) - Supplies and utility operating cost indices (for example, electrical power, explosives, labor and wages, machinery, steel, wire cable). The Bureau also issues the CPI.

- Engineering News-Record-Building and construction indices (for example, building materials, earthwork, and construction). Note that R.S. Means indexing is based on Engineering News-Record indices.

The U.S. Department of Labor Bureau of Labor Statistics issues the CPI and PPI. The CPI includes goods and services provided by business and government that are paid for by consumers. The PPI represents producer revenue and tracks output by domestic producers including construction products and services. The two indices diverge and are used for separate purposes. Industrial output and products are grouped by the North American Industry Classification System. The PPI provides both seasonally adjusted and nonseasonally adjusted data. Seasonally adjusted price changes reflect trends resulting from weather conditions, regular production and marketing cycles, model adjustments, seasonal discounts, and holidays. Nonadjusted values are related to actual dollar transactions and are of primary interest to cost analysts, marketing specialists, and purchasing agents to escalate long-term purchasing contracts.

The Engineering News-Record tracks historical cost over a moving 40-year period, currently from 1967 to 2019, as referenced by R.S. Means "Heavy Construction Cost Data" (Hale, 2019). An example of the use of historical indexing is the overall 6 percent increase in the general cost of construction and similar activities in the United States from $2012 \$$ to $2019 \$$. The average index includes hundreds of components and each component varies at different percentage rates.
Multiple indexing has been used in USGS coal assessments to determine project component costs. An argument in favor of expressing economic analyses in terms of escalated dollar values is the usefulness of multiple indexing in determining project component costs.

Large, multicomponent systems and processing plants are often indexed using the rule of six-tenths. In equation 8 , the sixth-tenths rule, the new index divided by the old index is bracketed with an " $n$ " exponent that can vary from 0 to 1 (Dysert, 2005). A 0.6 exponent is commonly used as being the most statistically significant value (Dysert, 2005). The six-tenths rule is also applied when costs are known, and a process or system is being scaled up or down. The size can refer to a process plant size, building size, or production level:

$$
\frac{\text { Cost }_{\text {new }}}{\text { Cost }_{\text {old }}}=\left(\frac{\text { Size }_{\text {new }}}{\text { Size }_{\text {old }}}\right)^{\mathrm{n}} \rightarrow \text { Cost }_{\text {new }}=\text { Cost }_{\text {old }} \times\left(\frac{\text { Size }_{\text {new }}}{\text { Size }_{\text {old }}}\right)^{0.6}
$$

The six-tenths rule is generally applied to large-scale, order-of-magnitude costing because it loses its effectiveness in costing smaller components. The exponent " $n$ " in equation 8 includes the range of $0-1$ with 0.6 or 0.7 being the average value for most applications. Variations in assigning a value for " $n$ " are associated with particular industries. A value other than 0.6 might be applied to a specific industry where experience has shown that a value such as 0.7 might be appropriate for specific chemical-leaching process applications. An example calculation using the six-tenths rule is shown in table 11. The escalation equation (equation 7) is a form of the six-tenths rule with the exponent $n=1$.

The new cost in table 11 becomes $\$ 361$ million if the exponent is equal to 0.5 and $\$ 315$ million if the exponent is equal to 0.7 . This range of values has a variance of 6-7 percent from the mean of $\$ 337$ million, which is well within the added contingency allowed for order-of-magnitude cost estimates. Applying the six-tenths rule is an acceptable, quick means of determining an overall cost in USGS coal assessments that allows an estimator to cost multiple similar projects without performing exhaustive model detailing.

Table 11. Calculation of six-tenths rule for cost escalation.

Find the overall approximate cost of a smaller surface coal mine from the cost of a larger mine when production is known.

\begin{tabular}{lll}
\hline & \multicolumn{1}{c}{ Mine A } & \multicolumn{1}{c}{ Mine B } \\
\hline Production & 10 million tons & 5 million tons \\
Total cost & $\$ 511$ million & New $\$$ \\
Calculation & & New $\$=\$ 511$ million $\times\left(\frac{5 \text { million tons }}{10 \text { million tons }}\right)^{0.6}$ \\
& & \\
& $N e w \$=\$ 377$ million
\end{tabular}




\section{Cost Estimating Components}

Economic evaluations for USGS coal assessments are largely an effort to identify and quantify the costs that are incurred in a normal mining operation. As a USGS economic mine model is similar to a commercial mining model, a commensurate level of design and costing detail that is complete in scope and accuracy is sought. The cost of doing the business of mining generally breaks down into the two categories of (1) capital costs and (2) operating costs, both of which are described in the following sections.

USGS economic models for surface and underground mines usually are evaluated to an extent that includes identification of total life-cycle costs and analysis on an after-tax basis. Key cost components that are common in models for both surface and underground mines are identified in figure 3 .

Capital and operating project expenses and income are typically arranged by timelines as shown in figures 1,2, and 4 . Expenses can occur throughout the project, but income or revenue is generally derived during the production phase. However, income generation can also occur during the postproduction phase with the sale of used equipment as salvage and through reimbursement of a reclamation bond. Costs associated with figure 3 expenditures can occur at different points in a project timeline. Such expenditures can occur during more than one of the principal mining functions shown in figure 4 . An example is the initial purchase of certain mining equipment during the preproduction phase followed by one or more additional purchases to replace worn-out equipment during the production phase.

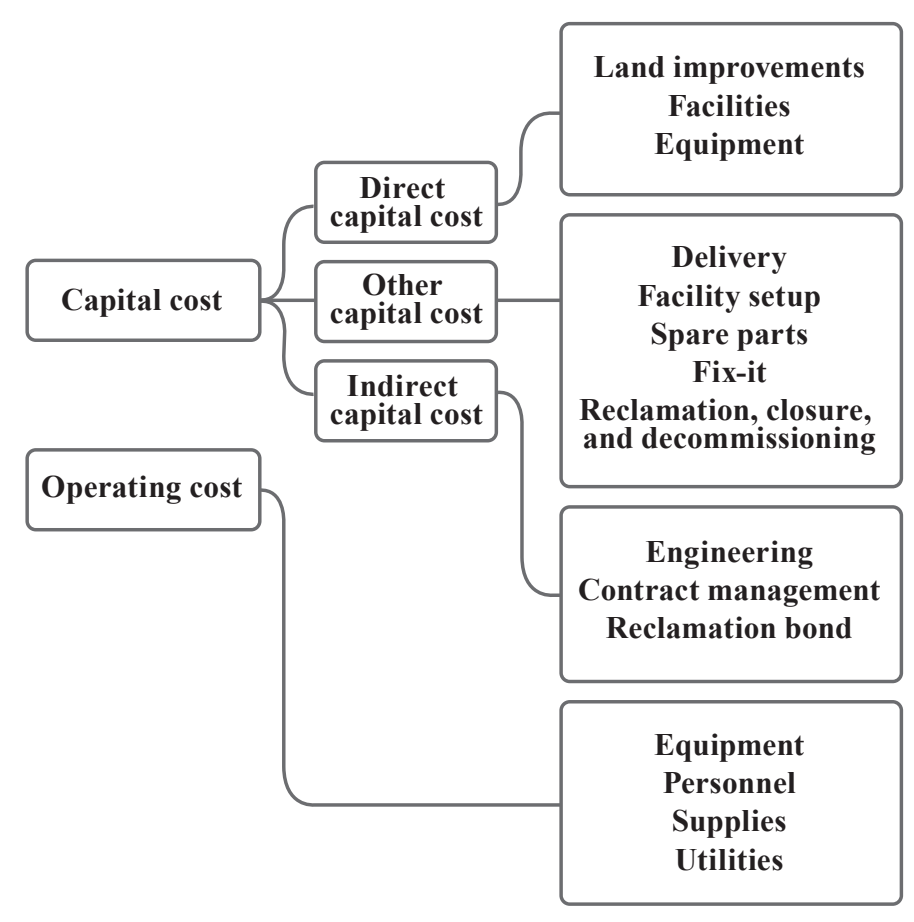

Figure 3. Diagram showing a breakdown of the costs considered in economic models for mines.

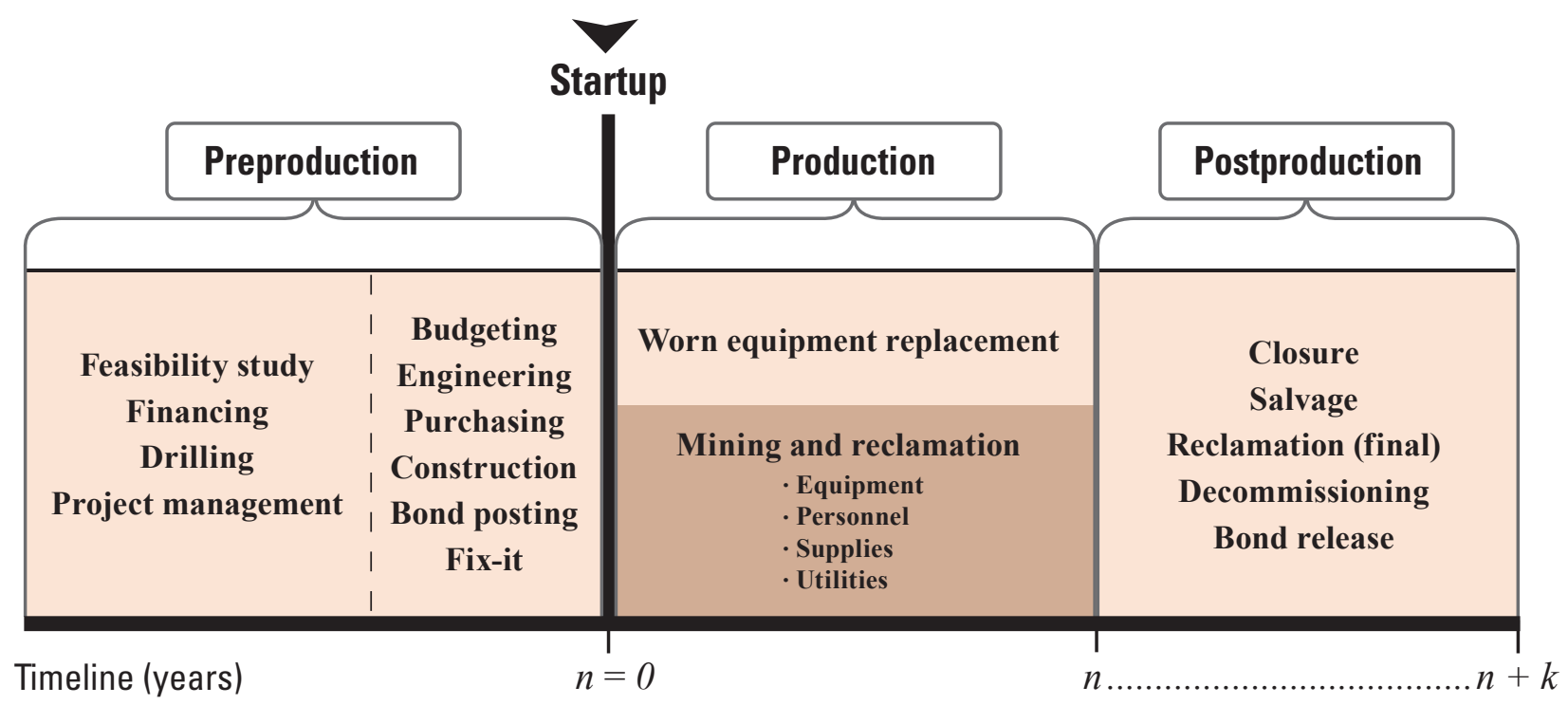

\section{Explanation}

Capital cost

Operating cost

Figure 4. Project timeline showing principal mining functions. (n, end of production; $\boldsymbol{k}$, end of postproduction) 


\section{Capital Cost Description and Appropriate Use}

Capital costs are expenditures for goods and services and are investments to accomplish an economic aim. Costs of assets of a business that can be bought and sold, including equipment and facilities, are capital costs. Ordinary and necessary expenses associated with these assets are tax deductible and, therefore, are operating costs. Capital costs are incurred for activities performed during the preproduction, production, and postproduction phases of a project. In addition, capital expenses can be incurred for equipment or facility replacement any time during the mining production phase. Several special cases have been examined and ruled upon by the IRS that supersede any general practice formally in place. The following three examples, which pertain to coal mining, show how costs can either be designated as capital costs or operating costs by the owning company.

1. Example of the use of contractor services.

- Contract services as capital costs.-O Owning corporation contracts another entity to conduct mining.

- Contract services as operating costs.-Owning corporation conducts mining and contracts another entity to provide services supporting mining.

2. Example of building a private road for the business.

- Road building as a capital cost.-Initial road construction and extensions of the initial road. Upgrade from a gravel cover to pavement as an improvement.

- Road building as an operating cost.-Normal road maintenance including blading, watering, and additional gravel are tax deductible and, therefore, operating costs.

3. Example of coal recovery during initial mining. Surface coal mining usually requires initial excavation to either establish a box cut or the outlines of an open pit for the production phase. Either can take several months to complete. Underground coal mining requires initial excavation of shafts and (or) ramps, main access openings, and rooms. The cost of these activities can either be treated as a capital or operating cost.

- Initial mining as capital cost.-Coal is recovered, permanently stockpiled, and never sold (wasted).

- Initial mining as operating cost.-Coal is recovered and sold for income (temporarily stockpiled or directly shipped).

\section{Direct Capital Costs}

Direct capital costs are essentially those assets that can be seen, such as equipment and facilities. These are major capital items that require expenditures, such as land improvements for the plant site, buildings, water treatment and fuel storage, plant site stationary and mobile equipment, and coal handling facilities at the plant site. Other capital expenditures that can be substantial are costs for delivery, setup, fix-it (initial correction), and spare parts. These costs are incurred initially to correct problems in assembly and set up, and malfunctions. If these expenditures are substantially delayed (no time limit specified), they become operating costs. Spare parts are usually warehoused to allow a continuous operation following project startup. These spare parts are a legitimate form of working capital, which is not to be confused with a cash deposit, but are better referred to as "inventory credit" (see the "Inventory Credit" section). Spare parts that are purchased during income-producing activities are treated as operating costs, but inventory credit is a capital cost.

Some expenditures, such as for research, exploration, and development, may be incurred well in advance of the preproduction phase. These costs may or may not substantially affect the outcome of an economic estimate depending upon their treatment. Also, they may belong in corporate financial evaluations as general expenditures and not be project specific.

\section{Indirect Capital Costs}

Certain capital costs are designated as indirect. Indirect capital costs are not a fixed part of a generic project but are a portion of the total capital costs that vary by industry and application. In USGS surface and underground mine models, indirect capital costs include primary engineering design and planning, preproduction activities (construction management), home office owner costs, construction facilities and equipment, quality assurance and quality control surveys, and commissioning/decommissioning expenses. Large mining projects have indirect capital costs that are a minor portion of the overall expenditure and generally within an 8-12 percent range.

\section{Capital Cost Categories}

Capital expenditures may be treated in several ways that are beneficial to owners or backers of a mining project. However, some of these expenditures may be misapplied when the boundaries between economic and financial evaluations and regionwide resource assessments are blurred. The economic mine models that are discussed in this report avoid creative application of investments and only provide a means of general resource valuation. The use or nonuse of common capital cost treatments in the USGS mine models is based on mining analogs, local and regional social-economic conditions, and appropriateness of these treatments in the cost estimate. These cost treatments are summarized in table 12 and discussed in the following sections. 


\section{Amortization}

Amortization is a cost recovery classification for items that are intangible or cannot be seen. Amortization is the deduction of capital expense over time. All capital costs that are amortized use a straight line depreciation method of cost recovery, as described in appendix 2. Amortization and depreciation are similar but are used for different purposes. Amortization is used by corporations to pay off a debt incurred for business startup, interests in corporations, land interests, computer software, and similar expenses. Intangible assets described in Tax Code Section 197 can also be amortized. Section 197, as presented by IRS Publication 535 (IRS, 2018b), includes nonvisual and untouchable items, such as goodwill, business records, patents, licenses, and trademarks. Intangible expenses are excluded from economic mine models if they do not substantially affect the economic outcome of an evaluation. Amortization is retained as a potential capital cost treatment for estimates of activities that are predominantly research or with similar functions that have a minimum of physical capital assets.

\section{Depleting Coal Resources}

Depletion is defined by the IRS in Publication 535 as "the using up of natural resources by mining, drilling, quarrying stone, or cutting timber" (IRS, 2018b, p. 35). An operator is allowed a tax deduction for the reduction of the natural reserves through either cost or percentage depletion. The method that gives the larger deduction is chosen. Depletion (cash or percentage) cannot be taken by corporations for coal that is stockpiled for more than 1 year or retained by a contractor.

Depletion allowance on a project site-by-site basis can substantially affect economic outcomes. However, this allowance becomes indeterminate over the wide expanse of a coal basin because all the area within the basin is not occupied by working leases. In a coal basin, the unmined portion generally dwarfs the mined portion so that neither the cost nor percentage depletion offers a substantial economic advantage to basinwide coal resource evaluation. However, a more closely defined assessment area increases the impact of coal depletion calculations on the breakeven cost and depletion may be used in future mining economic evaluations.

\section{Depreciation}

Depreciation is a reduction in the value of an asset over time. The asset must be a tangible item that has form and can be seen. A tax deduction can be taken for depreciation that results from reasonable exhaustion, wear and tear, and obsolescence of property. Although amortization is used to pay off a debt, depreciation is a measure of a loss in value and a corporate tax item. The following policies apply to the depreciation of mining assets.

- Both tangible property (buildings, machinery, vehicles, furniture, and equipment) and intangible property (including patents, copyrights, and computer software) can be depreciated. However, tangible property cannot be amortized.

- Land cannot be depreciated as it does not wear out, but improvements to the land (such as terracing, landscaping, and construction of water courses) can be depreciated.

- Intangible property can either be depreciated or amortized; the choice is made with a one-time election when filing income tax returns or when structuring project capital cost for an assessment.

- To be depreciable, property must have a determinable useful life.

- Worn-out and obsolete property is not depreciable.

Alternative depreciation system methods and their applicability are discussed in appendix 2 .

Table 12. Capital cost treatment actions.

\begin{tabular}{ll}
\hline \multicolumn{1}{c}{ Category } & \multicolumn{1}{c}{ Description } \\
\hline Amortization & Cost recovery of intangible capital assets \\
Depleting coal resources & Tax deduction for using up a natural resource \\
Depreciation & Cost recovery of tangible capital assets \\
Mine development ${ }^{1}$ & Nonproductive excavation, construction, and general tasking \\
Exploration & Determining location, thickness, extent, amount, and quality of a natural resource \\
Capital replacement (reinvestment) & Reinvestment to replace worn-out capital assets \\
Research & Scientific, social, or technical inquiries for project development \\
Salvage & Income from resale of functional, used capital assets \\
Inventory credit & Supply inventory to cover disruptions during project startup \\
\hline
\end{tabular}

${ }^{1}$ Development is excluded from surface mine models but included in underground mine models. 


\section{Mine Development}

Development or construction is a key phase in life-of-mine activities. Associated expenses may be deducted (treated as operating costs) or capitalized (depreciated or expensed) in accordance with Section 7 of IRS Publication 535 (IRS, 2018b). Mine development may occur as a preproduction activity or as a periodic, ongoing activity. Expenses are treated as capital costs in the former case and as capital or operating costs in the latter. Surface mining development costs are assumed to be insignificant in the total life-cycle costs and are not included in USGS models for surface mines.

Underground mining development costs can include expenses for shaft sinking, ramp construction, underground station excavation, and preproduction main entry excavation. These costs are either treated during the year incurred or aggregated with other preproduction costs in Year 0.

\section{Exploration}

The exploration phase, as described in this report, encompasses all activities related to determining the location, thickness, extent, amount, and quality of a coal deposit. Prospecting, land acquisition, contractual assessment, and the payment of legal fees may be included as well. These are capitalized costs in general accounting and are recovered through cost depletion or as an abandoned loss tax deduction. However, these costs also may be recovered as operating costs before the development phase of the mine (IRS, 2018b). Coal exploration expenses are included in the economic evaluations of mining operations if they are ongoing during development and (or) production in applicable mining analogs.

\section{Capital Replacement (Reinvestment)}

Capital replacement is the infusion of a new capital investment to add new property to take the place of property that is exhausted, worn, or obsolete. Replacement is an investment following a normal service life of capital items that are either amortized or depreciated. Equipment useful life and depreciation schedules are assumed to be essentially the same. Typical service or useful life of machinery is shown in appendix 2, table 2.2.

Certain large items (draglines, shovels, mine hoists, surface ventilation fans) are often used, at least in part, for many years past the tax-specified depreciation period. A dragline with a 30 -year service life for major structural components can only be depreciated over 7 years and may have an additional 10 -year life beyond a 20 -year mining project. A dragline should be more properly regarded as a system of working components in which each has a separate service life. The costs for draglines and large mine hoists in USGS assessments are not new equipment costs. Used dragline and mine hoist machinery and supporting equipment systems are commonly being used in industry due to current low demand for new items. A used dragline is sold at rates of one-eighth to one-quarter or less of its original price. Other large equipment systems are assumed to follow the same trend.

\section{Research}

Research and experimental costs are generally classified by the IRS as capital expenses in Section 7 of IRS Publication 535 (IRS, 2018b). Any costs incurred that are reasonable and necessary to eliminate uncertainty about an activity or product can be amortized and (or) expensed (depreciated) in the year incurred. Research and experimentation may include both tangible and intangible capital expenses. (See the "Amortization" and "Depreciation" sections for information on which classification applies). Publication 535 also lists acceptable cost items including formulas, inventions, patents, pilot models, processes, techniques, and property. Some items that are not included are efficiency surveys, management studies, quality control testing, and historical research. Research costs might be added to project costs for technological innovations in coal recovery.

\section{Salvage}

Some property may have a value at the end of its useful life, which coincides with the end of a project or occurs some time during a project life when the property is no longer used. Resale of the property is considered salvage. Resale provides income during the postproduction period and is discounted to NPV. The value of a property after the initial purchase is usually lower than the original cost by the amount of wear, obsolescence, and inflation rate.

Salvage after a long project life, such as a 20 -year period, is minor, so it does not appreciably contribute to the overall economic viability of a project. For example, the salvage may be about 1 percent or less for a $\$ 100$ million or more capital investment. For shorter mine life periods, salvage has a greater economic advantage. Salvage is delayed income in USGS coal assessments and including it is optional depending on the length of the project and the amount of the initial investment.

\section{Inventory Credit}

The IRS permits a special tax treatment item for "inventory, Spare Parts" that allows a short-term allowance (3 months) for parts that are bought and stored to bridge a potential supply difficulty during the opening days of the operation (26 CFR §1.162-3). 
If all of these parts are not needed or used as planned, the extra supply can be slowly melded into the operation without penalty. After some time, perhaps a few weeks or months, the original spare parts inventory will be exhausted and additional spare parts will be purchased as operating cost items. A corporation may be wary of having a large spare parts component because spare parts purchased with current dollars will cost more per item by the time the oversupply is exhausted than the component would have cost if purchased with future dollars when needed. Therefore, mining operations typically do not maintain large supply inventories due to unfavorable economics. An inventory credit of about 3 percent of total machinery purchase cost is applied to all USGS mine models as a direct other capital cost item but is not included as a tax credit.

Many mining economic evaluations apply working capital instead of the inventory credit or spare parts category to pay off short-term liabilities of an operation. This is a misapplication in economic evaluations as it lacks the specificity that the IRS requires for tax deductibility. Working capital is more properly applied to a corporate balance sheet as a current asset less liabilities and, as such, is a component of financial analysis and is not included in USGS coal assessments. If a working capital component is included in a commercial mining cost evaluation, it is likely treated as a catchall for any unexpected ills, such as disruptions in business income, liabilities, or other unplanned demands, that might occur and, therefore, it blurs the intent of economic analysis, which is to evaluate the merit of investments. A company may wish to inflate its asset value projections by adding working capital to offset excess liabilities and provide a seemingly better financial picture. From a strictly financial standpoint, the size of the working capital is one measure of a company's strength and may indicate a poorly run enterprise. Also, an economic study that includes a working capital component is attempting to anticipate a sizable risk to operations at some later date. The economic study is likely to impose too small a contingency cost as a result, with the idea that the working capital component will duly compensate. Both the company's financial balance sheet and the economic assessment are then flawed.

\section{Operating Costs}

Operating costs are ordinary and necessary expenses associated with assets and are the recurring expenditures incurred in conducting mining activity. Operating costs occur during production as annual uniform amounts including personnel, supplies, and utilities. The determined NPV for these expenses is subtracted from total income as a tax-deductible item. Equipment is not included in operating costs but various costs associated with equipment, such as costs for tires, grease, oil, water, electricity, wire cable, and other items, are included. Equipment maintenance is usually conducted by mine employees as an operating cost. Conversely, equipment rebuilds for major coal companies are conducted by contract labor, so are treated as capital expenses.

\section{Taxes and Royalty}

Taxes are direct charges against income that are levied by designated authorities (Federal, State, and county governments; municipalities; and private owners) for the privilege of extracting a coal or mineral resource within their jurisdictions. Taxes include the Federal excise tax (currently 4.4 percent of sales income), Federal income tax (currently 6.75 percent of net income), State corporate income tax, county property tax, sales and use tax, motor fuel tax, and coal severance tax. Royalty is a form of severance tax that varies by State and is based on the amount of annual tonnage recovered from within ownership boundaries. Non-Federal taxes including royalties are highly variable, but royalties and Federal taxes together generally fall within 40-60 percent of the calculated net profit. IRS regulations allow certain items to be deducted (including amortization, depletion, depreciation, and operating costs) before taxes are imposed. Taxes on income are project costs like personnel and similar costs. Evaluations performed on an after-tax basis are necessary in determining the real income to support total project costs.

\section{U.S. Geological Survey Evaluation Approach}

\section{Capital and Operating Cost Estimating}

Capital and operating costs are handled in USGS coal assessments based on the fundamental economic principles detailed previously in this report. Assessments can be performed using any amount of previous or current mining information. Added cost to a base estimate or cost contingency can vary from +30 percent of the base estimate to +50 percent or more depending on the thoroughness and reliability of design information. Although surface mine modeling of near-surface coal deposits and underground mine modeling for deeper deposits are substantially different, the method of costing is essentially the same.

\section{Surface Mine Costs}

Surface mining is performed in a cycle of sequential loading and hauling steps using large excavating equipment (draglines, shovels, wheel loaders, haulage trucks) for overburden removal and coal recovery. Typically at surface mines, secondary equipment systems provide support for accomplishing these steps; these systems use top-down and lateral sweeping earthmoving methods.

Earthwork calculations are performed to simulate mass excavation that would be expected for an actual mining operation. Equipment capacity and performance are calculated for primary loading and hauling equipment from the key mining inputs given in table 13. 
Mining equipment represents approximately 40 percent of the total capital investment in USGS coal assessments. For mining economic models, this expenditure is largely derived from the above parameters for sizing loading and hauling equipment. Other mining equipment (drills, bulldozers, graders, and service trucks) are preselected, have default but changeable costs, and may be used for a wide range in quantity and capacity of loaders and haulers. An additional 60 percent of overall capital investment lies in nonmining equipment, site preparation, facilities, haul road construction, and smaller miscellaneous charges.

\section{Underground Mining Costs}

The capital cost profile for underground coal mining in USGS coal assessments differs substantially from that for surface mining. Approximately, 40 percent of the overall capital investment is placed in the mining equipment. Underground mining is a more specialized means of coal recovery in that the overburden is left largely intact and much unproductive work is performed before coal revenues are realized. Large amounts of noncoal may be removed at surface mines, but underground mining is conducted within the coal bed without removing appreciable amounts of noncoal. Because a large portion of the coal is left in place to provide structural support for the underground excavations, the overall percentage of coal recovery is reduced. Excavating for structural support incurs about 30 percent of the overall capital investment and includes constructing ramps, shafts, and underground support facilities. Nonmining equipment, surface facilities, and various miscellaneous expenses cost an additional 30 percent.

For economic models for underground mines, all equipment and facilities are preselected for a given coal production rate that corresponds with a nearby or regional mining analog. Underground excavation for access to production areas are between 16and 20-feet wide with pillar widths and lengths sized to maintain the static load of the overburden. Ground control appliance types and quantities are preselected as lump-sum costs.

\section{Costing Risk Mitigation in Economic Evaluations}

Estimating project costs is fraught with many unknowns and the probability is high that unexpected events will occur and produce unexpected outcomes. Uncertainty lies in the very large range of potentially cost-affecting social and technical issues in addition to potential disruptions because of changes in natural conditions. These impacts are often not fully considered by estimators and managers or are misrepresented to produce favorably biased studies (Bertisen and Davis, 2008). Mining is a dynamic activity in which new and unexpected features, events, and processes constantly occur.

A study of more than 1,015 mining projects throughout the world shows that overruns of cost estimates are quite common with the average overrun being 22 percent (Bertisen and Davis, 2008). Whether these mistaken estimates are the result of estimator inexperience, political expediency, or unknown problems, the affected mining companies often experienced threats to their profitability. Every cost estimate holds some degree of risk in meeting expected targets. Contingency is a measure of the risk in obtaining the estimated cost and a function of project definition and expected accuracy (Rothwell, 2005). Contingency is an additional charge applied to a cost estimate. Contingency does not include specification changes, strikes, natural disasters, management reserves, escalation, or currency fluctuations.

The balance between uncertainty and knowledge is graphically shown in figure 5. As knowledge increases, uncertainty decreases. A consequence of this relationship is a decrease in the degree of risk with a decrease in uncertainty. However, the envelope of uncertainty never entirely converges upon the estimated value even when the project is "fully" defined in a definitive cost estimate.

Perhaps the best guidance on contingency, including how it differs among industries and how to apply it, was developed by AACE through contributions by several supporting sources. One early source used in AACE literature that serves as a basis for this report is "Cost Contingency for Investment Estimates Involving New/Evolving Technology" (Cabano, 1989). The amount of available project information largely determines the

Table 13. Key mining inputs in U.S. Geological Survey coal assessments.

\begin{tabular}{ll}
\hline \multicolumn{1}{c}{ Inputs } & \multicolumn{1}{c}{ Description } \\
\hline Coal bed orientation & Angle of beds use a horizontal default value but can be inclined to vertical \\
Coal and noncoal thickness & Apparent thicknesses of coal and noncoal beds \\
Coal recovery & Percentage of excavated coal delivered for shipment; from 0 to approximately 5 percent lost \\
Coal and noncoal characteristics & Coal and noncoal in-place densities and swell factors caused by breaking and heaving \\
Number of highwalls/benches & Single vertical pit side cut or multiple vertical cuts (benches) \\
Excavation factors & Loader-bucket fill amount and comparative loader cycle times to fill haul trucks \\
Work time allocation & Comparative schedules with number of hours/shift, shifts/day, and days/year \\
Machine efficiencies & Time available on a minute/hour basis and maintenance utility on an hour/year basis \\
Haulage truck fleet & Number of haul trucks matching loader capacity and performance; 3 to approximately 5 trucks/loader \\
\hline
\end{tabular}


level of accuracy in a cost estimate. The relationship between the degree of project definition and expected accuracy is shown in table 1 and figure 6.

The accuracy of estimating costs as shown in table 1 depends on the technological, geographical, and geological complexity of a mining project. The ability to achieve the estimated cost can be hampered by the inherent risks of unrecoverable coal and deteriorating coal quality. The importance of table 1 is the balance of information and preparation with the accuracy of an estimate. The accuracy becomes more tightly bound with each succeeding level of estimate, which is graphically demonstrated in figure 6 as a converging space toward a narrow target. In an economic mining evaluation, a contingent amount of additional capital is included as a reserve fund to compensate for changes in project scope and costs associated with uncertainty. AACE suggests a 30 percent contingency for a Class 4 estimate or feasibility study and 50 percent for a Class 5 estimate (Rothwell, 2005). Adding an additional 30 percent amount of capital to a $\$ 100$ million mining investment increases the cost to $\$ 130$ million.

AACE cost estimating guidelines have been widely adopted by government estimators. The relationship between accuracy and project stage is essentially the same for both commercial and governmental applications.

\section{Leasing and Purchasing Equipment}

Mining operations may purchase or lease primary equipment. Either choice has potential financial advantages and disadvantages. Leasing can be advantageous for the following reasons.

- Equipment leasing charges may be written off for tax purposes in the year in which they occur as an operating cost, whereas purchased equipment may have to be depreciated so expensing equipment costs in a single year may be limited.

- Leasing provides additional lines of credit over normal lines of credit.

- Leasing leverages potential profits without increasing capital investment and, thereby, improves the ROI.

- Leasing provides flexibility when a speculative project proves unsuccessful by reducing the risk of committing capital and experiencing sunk cost.

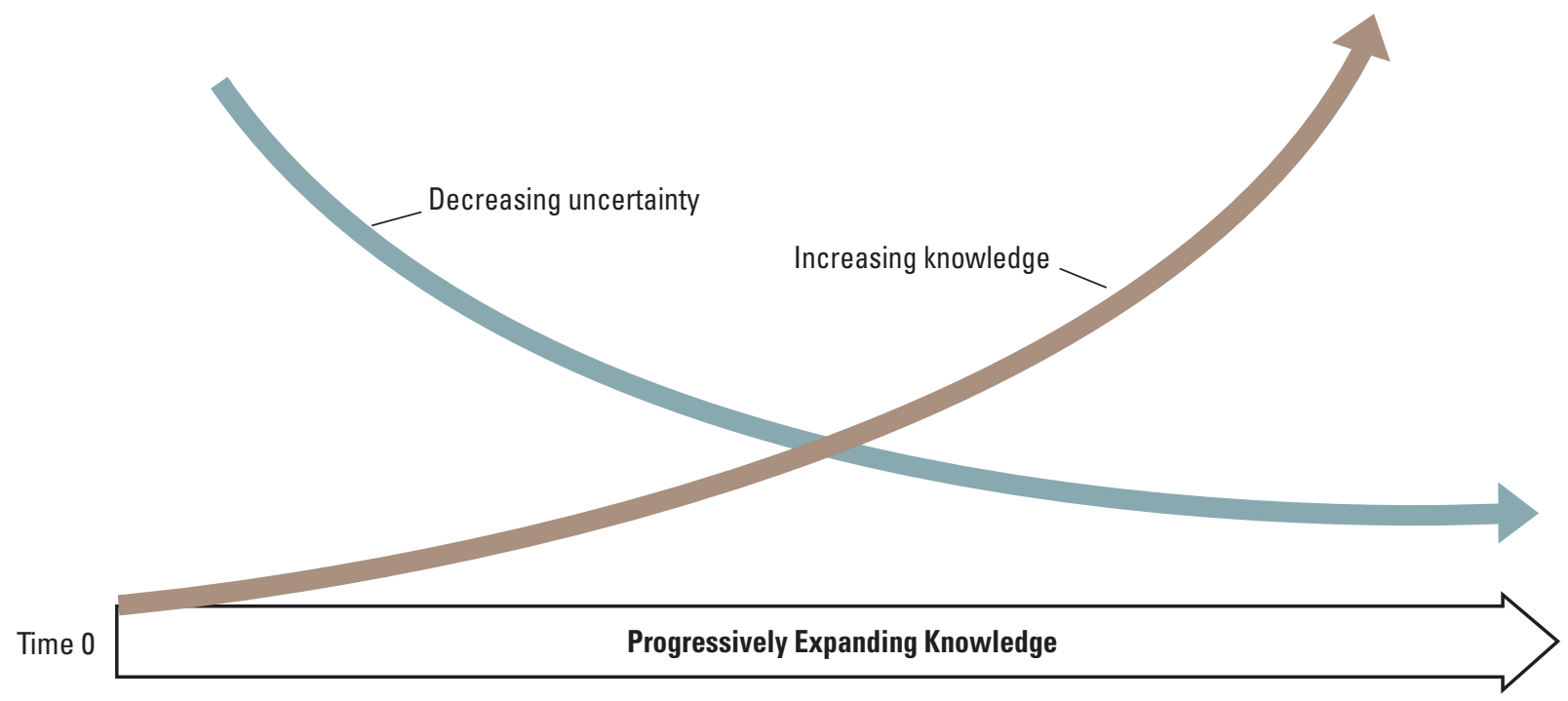

Figure 5. Diagram showing the relationship between uncertainty and knowledge at different stages as knowledge of the mining operation expands (modified from Cabano, 1989). 
In addition, for some coal mining projects, leasing machinery may be more profitable than purchasing machinery. This is because lease payments are deferred at a lower NPV, which is a time value of money advantage compared to applying the purchase price at current cost. Cost deferment is advantageous for USGS coal assessments as well. Leasing may be included in USGS evaluations if it is a common practice in the mining analogs. Leasing is also common for contractors on mining projects and the contractor may include the lease as part of the fee incurred by the mining company (a capital cost) or the mining company may assume the burden of the lease (an operating cost).

\section{Breakeven Evaluation}

The calculation previously shown in table 3 is used to determine the amount of capital investment that is needed to produce a projected income. A price is contracted for the sale of a given tonnage of coal, so income is equal to the price per ton multiplied by the number of tons sold (Income $\$=\$$ / ton price $\mathrm{x}$ tons sold). However, income is unknown if the price per ton is unknown. As cash flow is income less operating cost, the potential income needs to be calculated. This is performed as shown in table 14 .

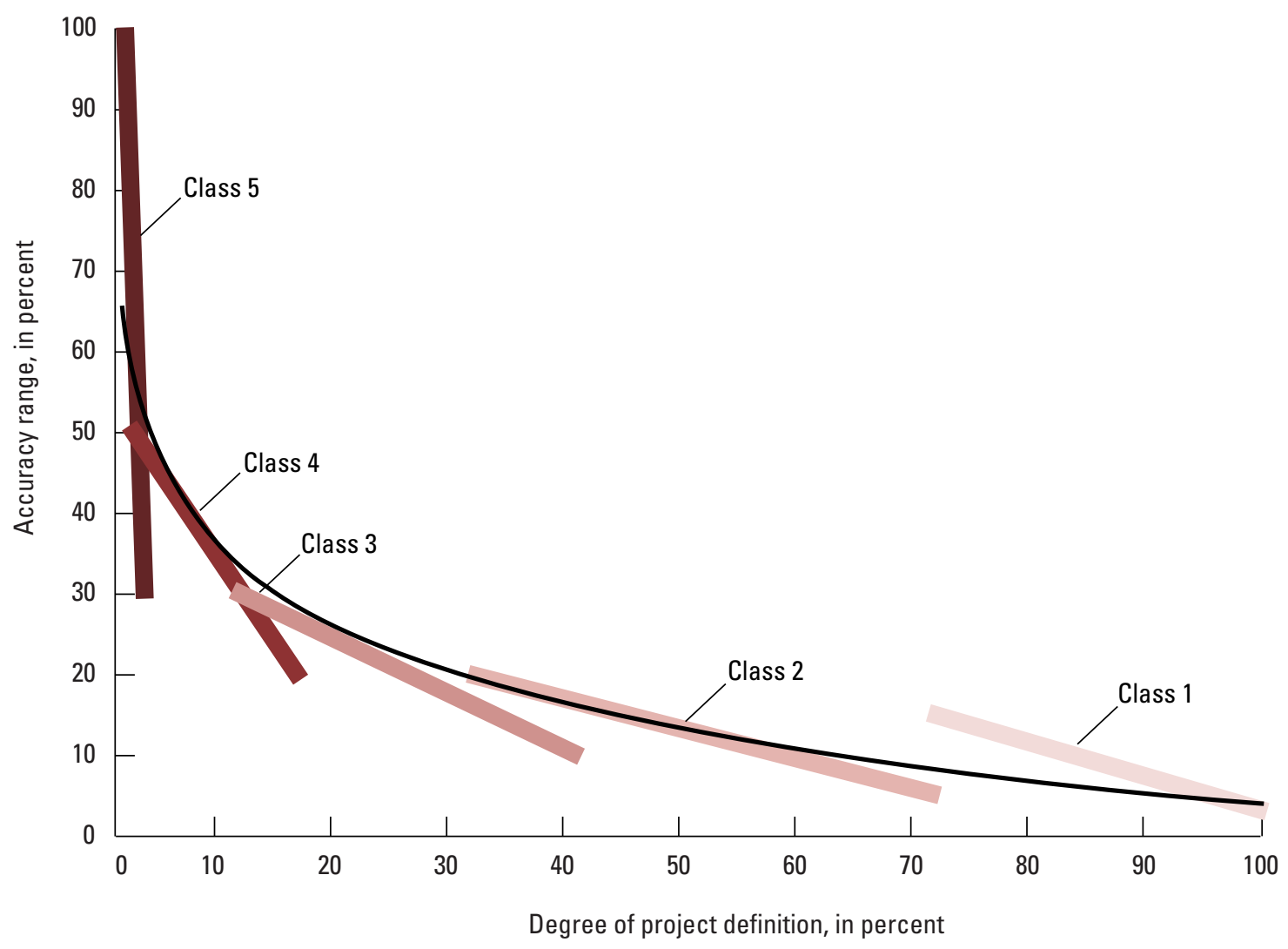

Figure 6. Diagram showing the relationship between the accuracy of cost estimates and the degree of project definition for different classes of cost estimates (modified from U.S. Department of Energy, 2018). The black line represents the level of uncertainty. 
The capital cost of a mining project is calculated for a rate of coal recovery suitable for the area after considering the site's geological conditions and applying an appropriate mining method with its attendant components (machinery, personnel, supplies, and so on). This capital cost is compared with a cash flow for which the income is unknown and determined using the formula in table 14 . The tonnage determined in developing the capital cost is divided into the calculated income to yield the cost per ton that would be needed to produce the required income. This is the breakeven cost.

Project profitability for a commercial interest would result if the breakeven cost is less than the market (sales) price; if a breakeven cost exceeds the market price, the project would be unprofitable. Commercial interests have additional economic calculations to perform to determine the potential profitability before a mining project is untaken. However, for USGS coal assessments, a profitability-unprofitability index will suffice where profitability equals tonnage of reserve and unprofitability equals mineable coal resource.

USGS coal assessments use a calculated average commodity price that is based on average pricing reported by the U.S. Department of Energy and the Energy Information Administration. For areas for which the Energy Information Administration or other sources do not report, a calculation can be used to provide a rough value of a coal deposit in the area. The calculation uses the average coal heating values for the assessment area. For example, assume that a bituminousrank coal with a thermal value of 11,700 British thermal unit per pound (Btu/lb) has a spot market price of $\$ 41.00$ per ton. Then, the calculation to find the relative market price for bituminous-rank coal with a thermal value of $11,580 \mathrm{Btu} / \mathrm{lb}$ is $11,580 \mathrm{Btu} / \mathrm{lb} \div 11,700 \mathrm{Btu} / \mathrm{lb} \times \$ 41.00 /$ ton $=\$ 40.58 /$ ton. The calculated price of $\$ 40.58$ per ton is then compared to the calculated cost per ton from the mining evaluation.

\section{Reserve Assessment}

Reserves are derived from the combination of a statistical geological model, a corresponding statistical mine model, and the average cost of coal recovery. The geological model identifies the volumetric amount of noncoal in units of cubic yards, mass of coal in short tons, and the noncoal and coal unit thicknesses. Noncoal and coal thicknesses and amounts are derived from isopach maps that are created from grids based on coal bed drill hole correlations. For near-surface deposits, the potential surface mining stripping ratio in each grid unit is calculated by dividing the total burden amount within each grid cell by the total amount of corresponding coal. Grid cell amounts, corresponding stripping ratios, and other data on geological conditions, if available, are then averaged for larger areas covering several townships. Burden and coal are assumed to be continuous unless discontinuities in actual deposition are noted. In this manner, geological characteristics are statistically averaged into a single set of geological conditions for which a mine model can be prepared.

A mine model is developed for a large area of land corresponding to the geological model. Various components of the mine model are costed for the hypothetical life of the mine and calculated for their NPV. Contingent cost is included in the capital cost component of the after-tax calculation shown in table 14 . Through this calculation, the breakeven cost is determined for the mining condition. This is the coal recovery cost per ton.

For surface mining, coal recovery costs are calculated for each stripping ratio of noncoal to coal from 1:1 to 10:1 or more. The stripping ratio-tonnage relationship from the geological model and the stripping ratio-cost per ton relationship from the mine model are combined into a graphical display of cost per ton as a function of the total tonnage calculated for the individual stripping ratios as shown in figure 7 . The near linearity

Table 14. Calculation of breakeven price per ton (modified from Stermole, 1974).

\begin{tabular}{cl}
\hline \multicolumn{1}{c}{ Parameter } & \multicolumn{1}{c}{ Description } \\
\hline Capital cost & Total capital investment during preproduction, production, and postproduction phases \\
& \\
Cash flow & Income less operating cost; equivalent to total capital investment \\
+ Salvage & Optional value; discounted over long mine life yields small value \\
- Deletion & Not generally used in U.S. Geological Survey coal assessments \\
- Depreciation & Accelerated rates at 200 percent and 150 percent plus straight line depreciation method \\
$=$ Net profit & \\
+ Taxes & Combined Federal, State, and local tax rates equaling about 50 percent of net profit \\
$=$ Taxable income & \\
+ Depreciation & Amount subtracted from cash flow is added to taxable income \\
+ Operating cost & Total deductible cost of doing business throughout the production phase \\
$=$ Income & \\
$\quad \div$ Tonnage & Total tonnage of coal recovered and sold \\
$=$ Cost per ton & Price-cost breakeven point \\
\hline
\end{tabular}


of the data allows direct correlation between the vertical and horizontal scales of the graph. The current or target market price for coal at the time of the economic evaluation is projected by moving from the cost per ton scale to the data line and then to the tonnage scale. This tonnage is the estimated surface mineable reserves. In figure 7, a market price of $\$ 13.20$ per ton corresponds to 12.8 billion tons of coal reserves. The strength of this approach lies in its flexibility. As the market price rises and falls, the corresponding reserve tonnage results may be determined by moving up and down the data line.

\section{Summary}

This report provides general guidance for performing economic mining evaluations of coal deposits using common recovery practices and standard economic principles. Mining evaluations are conducted using life-of-mine costs in net present value analyses. Because there is not a standard methodology for costing and manipulation of costs, a variety of analysis techniques are used.
The report compares the different methods used and purposes for cost estimating for commercial and governmental (U.S. Geological Survey) applications through examples of U.S. Internal Revenue Service rulings, economic calculations, and common financial practice. Recommended practices from AACE International are reasonable sources for performing cost estimation. However, they are recommendations and not quality standards. Interpretations that are made in the report are based on estimator's experiences of good practice with the backing of these authoritative sources, rather than derived from general literature sources.

Commercial and government interests are contrasted by the manner used and the purpose for which cost estimation is conducted. Although commercial economic analyses are often used in conjunction with financial calculations, no financial considerations are included in government economic analyses. USGS assessments determine potential project profitability in coal recovery and profitability is the measure by which USGS uses to delineate reserves from coal resources. The topics included in this report have been offered as a how-to methodology for conducting evaluations and properly applying economic concepts.

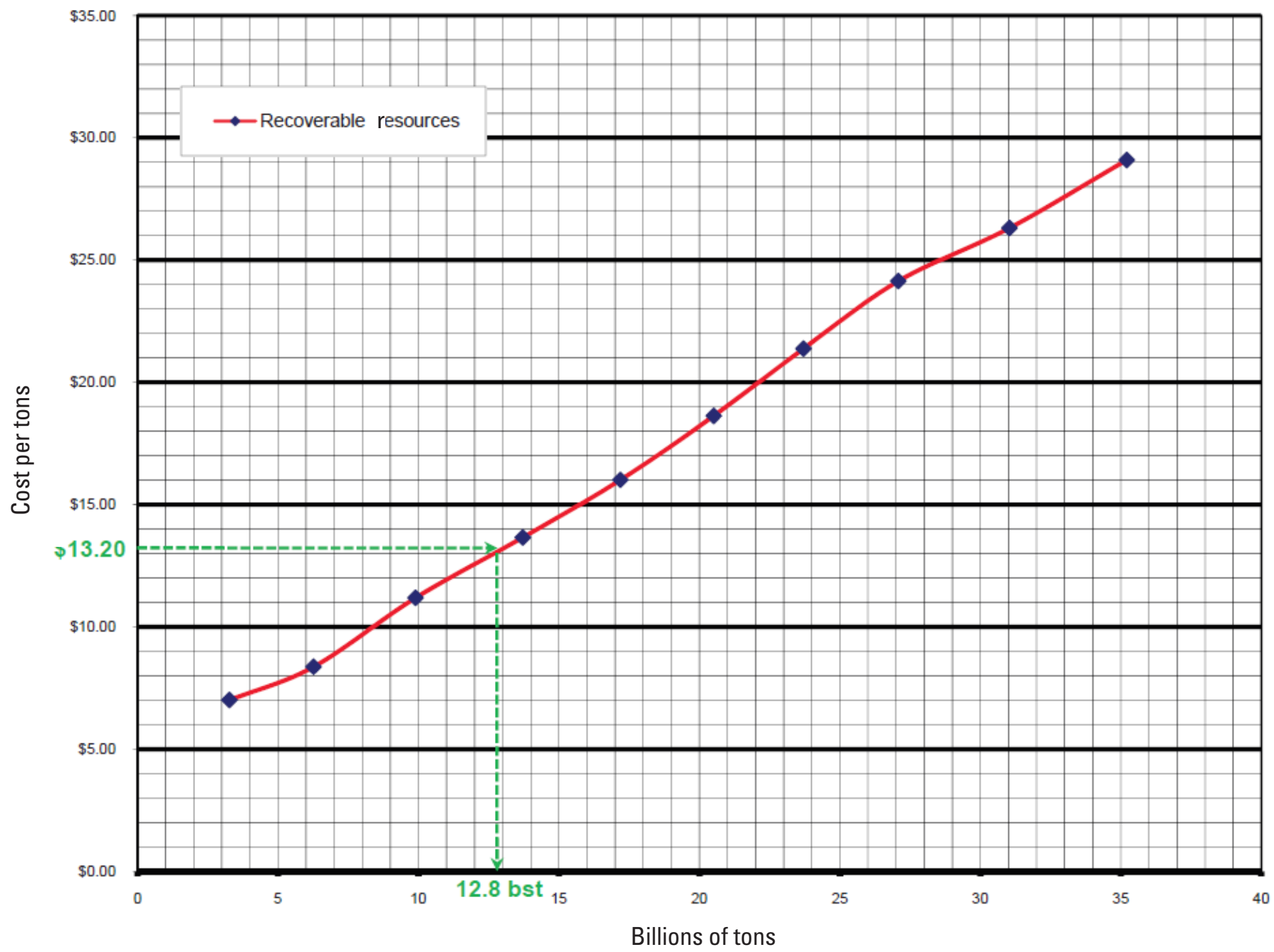

Figure 7. Graph showing surface coal mine reserve estimates (from Haacke and others, 2013, fig. 85; bst, billion short tons). 


\section{References Cited}

AACE International (AACE), 2012, Alliance for Quality Project Management between AACE International and the United States Department of Energy - Memorandum of understanding dated July 10, 2012: Morgantown, W. Va., AACE International, $4 \mathrm{p}$.

Bertisen, J., and Davis, G.A., 2008, Bias and error in mine project capital cost estimation: The Engineering Economist, v. 53 , no. 2 , p. $118-139$.

Board of Governors of the Federal Reserve System, 2019, Selected interest rates: Washington D.C., Board of Governors of the Federal Reserve System, accessed June 28, 2019, at https://www.federalreserve.gov/releases/h15/.

Bredehoeft, P.R., Dysert, L.R., and Hollmann, J.K., 2019, Cost estimate classification system, as applied in engineering, procurement, and construction for the process industriesAACE International Recommended Practice No. 18R-97, rev. March 6, 2019: Morgantown, W. Va., AACE International, $16 \mathrm{p}$.

Bredehoeft, P.R., Dysert, L.R., and Pickett, T.W, 2019, Cost estimate classification system-AACE International Recommended Practice No. 17R-97, rev. March 6, 2019: Morgantown, W. Va., AACE International, 9 p.

Cabano, L.J., 1989, Cost contingency for investment estimates involving new/evolving technology, in Uppal, K.B., ed., 2015, Professional Practice Guide \#08: Contingency, 4th edition: Morgantown, W. Va., AACE International, article 01-8, p. B.5.1-B.5.6.

Caterpillar, 1979, Caterpillar performance handbook, edition 10: Peoria, Ill., Caterpillar Tractor Co., 480 p.

Coinnews Media Group LLC, 2019, US inflation calculatorCurrent US inflation rates, 2009-2019: Coinnews Media Group LLC, accessed July 11, 2019, at https://www.usinflationcalculator.com/inflation/current-inflation-rates/.

Cooper, R., and John, A., 2012, The Fisher Equation—Nominal and real interest rates, chap. 16.14 of Theory and applications of macroeconomics, v. 1.0: Creative Commons CCO, p. 811-813, accessed July 11, 2019, at https://2012books.lardbucket.org/ books/theory-and-applications-of-macroeconomics/ s20-14-the-fisher-equation-nominal-an.html.

Dysert, L.R., 2005, So you think you're an estimator: Morgantown, W. Va., AACE International, 2005 AACE International Transactions, EST.01, 6 p.

Entrepreneur, 2019, Small business encyclopedia: Irvine, Calif., Entrepreneur, accessed June 28, 2019, at https://www.entrepreneur.com/encyclopedia.
Ferri, R., 2014, 30-year market forecast for investment planning, 2014 edition: Forbes Media LLC, accessed June 28, 2019, at http://www.forbes.com/sites/rickferri/2014/01/09/ portfolio-solutions-30-year-market-forecast/.

Haacke, J.E., Scott, D.C., Osmonson, L.M., Luppens, J.A., Pierce, P.E., and Gunderson, J.A., 2013, Assessment of coal geology, resources, and reserves in the Montana Powder River Basin: U.S. Geological Survey Open-File Report 2012-1113, 133 p.

Hale, D., ed., 2019, Heavy construction costs with RSMeans data, 33rd annual edition: Rockland, Mass., The Gordian Group, Inc., 741 p.

InfoMine, 2016, Mine and mill equipment costs-An estimator's guide: Spokane, Wash., InfoMine USA, Inc. CostMine Division, $348 \mathrm{p}$.

Internal Revenue Service (IRS), 2018a, Basis of assets: U.S. Department of the Treasury Internal Revenue Service Publication 551, revised December 2018, 14 p., accessed June 28, 2019, at https://www.irs.gov/formspubs/index.html.

Internal Revenue Service (IRS), 2018b, Business expenses: U.S. Department of the Treasury Internal Revenue Service Publication 535, dated Jan. 25, 2019, 65 p., accessed June 28, 2019, at https://www.irs.gov/formspubs/index.html.

Internal Revenue Service (IRS), 2018c, How to depreciate property-Section 179 deduction, special depreciation allowance, MACRS, listed property: U.S. Department of the Treasury Internal Revenue Service Publication 946, dated Feb. 15, 2019, 110 p., accessed June 28, 2019, at https://www.irs.gov/formspubs/index.html.

Investopedia, 2019, Financial dictionary: New York, Investopedia, accessed June 28, 2019, at https://www.investopedia. com/terms/.

Karlsen, J.T., and Lereim, J., 2005, Management of project contingency and allowance: Cost Engineering, v. 47, no. 9, p. 24-29.

Lapedes, D.N., ed., 1978, McGraw-Hill dictionary of scientific and technical terms ( $2 \mathrm{~d}$ ed.): New York, McGraw-Hill, $1,771 \mathrm{p}$.

Marchant, M.A., and Snell, W.M., comps., 1997, Macroeconomics and international policy terms: University of Kentucky Cooperative Extension Service, 4 p., accessed June 28, 2019, at https://web.archive.org/web/20070318072324/ http://www.ca.uky.edu/agc/pubs/aec/aec75/aec75.pdf.

Mine Safety and Health Administration, 2019, Mine Data Retrieval System: U.S. Department of Labor, Mine Safety and Health Administration, accessed June 28, 2019, at https://arlweb.msha.gov/drs/drshome.HTM. 
Office of Surface Mining Reclamation and Enforcement, 2017, Reclamation Performance Bonds (updated 4/24/17): U.S. Department of the Interior Office of Surface Mining Reclamation and Enforcement, accessed June 28, 2019, at https:// www.osmre.gov/resources/bonds/BondsOverview.shtm.

Rothwell, G., 2005, Cost contingency as the standard deviation of the cost estimate for cost engineering: Cost Engineering, v. 47, no.7, p. 22-25.

Stermole, F.J., 1974, Economic evaluation and investment decision methods ( $2 \mathrm{~d}$ ed.): Golden, Colo., Investment Evaluations Corporation, $449 \mathrm{p}$.

Thrush, P.W., comp., 1968, A dictionary of mining, mineral, and related terms: Washington, D.C., U.S. Department of the Interior, Bureau of Mines, 1,275 p.

U.S. Department of Energy [DOE], 2018, Cost estimating guide: Washington, D.C., U.S. Department of Energy, DOE G 413.3-21A, updated June 6, 2018, 153 p., accessed June 28, 2019, at https://www.directives.doe.gov/ directives-documents/400-series/413.3-EGuide-21A.

Wood, G.H., Jr., Kehn, T.M., Carter, M.D., and Culbertson, W.C., 1983, Coal resource classification system of the U.S. Geological Survey: U.S. Geological Survey Circular 891, 65 p.

Publishing support provided by:

Denver Publishing Service Center, Denver, Colorado

For more information concerning the research in this report, contact the Center Director, USGS Central Energy Resources Science Center

Box 25046, Mail Stop 939

Denver, C0 80225

(303) 236-1647

Or visit the Central Energy Resources Science Center website at: https://energy.usgs.gov/ 



\section{Glossary}

\section{A}

alternative depreciation system (ADS) A system of depreciating property over longer recovery periods than under general depreciation system guidelines using a straight line depreciation method. Allowed by the Internal Revenue Service (IRS) for specific conditions (IRS, 2018c).

\section{B}

breakeven cost The point at which the cost is equivalent to the income or revenue. Production level of operation at which income exactly equals total cost (Stermole, 1974).

\section{C}

cash flow Difference between income or revenue and expense that is calculated on a periodic basis (monthly, yearly, and so on). Positive cash flow occurs when revenue exceeds expense and negative cash flow occurs when expense exceeds income (Stermole, 1974).

class life Number of years that establishes the property class and recovery period under the general depreciation system and the alternative depreciation system (IRS, 2018c).

compound interest Application of interest on unpaid investment principal that is accrued each interest period (Stermole, 1974).

cost contingency A lump sum or percentage allocation added to a cost estimation to compensate for the risk of not attaining the estimate result (Cabano, 1989).

\section{D}

definitive cost estimate Highest degree of deterministic estimating that comprises all engineering and design documentation of a project (synonymous with full detail, tender, final) (Bredehoeft, Dysert, and Hollmann, 2019).

deflation Decline in prices, reduction in money supply, or rising purchasing power. Opposite of inflation (Investopedia, 2019).

deterministic (determinate) Bounded by definite limits.

\section{discounted cash flow rate of return}

(DCFROR) Percentage rate at which a capital investment is recovered or lost through periodic cash flows escalated (discounted) to a common point in time (Stermole, 1974).
E

economic analysis Systemized process of determining the merits of profitably expending funds for investment alternatives (Stermole, 1974).

$\mathbf{F}$

financial analysis Process of determining from where investment funds will be obtained (Stermole, 1974).

\section{G}

general depreciation system (GDS) A system of depreciating property using a 150-percent or 200-percent declining balance or straight line method over a specified recovery period (IRS, 2018c).

\section{I}

inflation Rate of rising prices and falling purchasing power (Investopedia, 2019).

inventory credit A short-term allowance (3 months) for parts that are bought and stored to bridge a potential supply difficulty during the opening days of the operation (26 CFR §1.162-3).

investment Purchasing assets for future generation of income (Investopedia, 2019).

\section{L}

life-of-mine The time through the employment of available capital or the time period during which ore reserves will be extracted (Thrush, 1968).

\section{M}

microeconomic theory Branch of economics that deals with the behavior of individual producers and consumers, particularly as decisions are made with respect to the allocation of limited resources (Marchant and Snell, 1997).

modified accelerated cost recovery system (MACRS) Basis of recovery of most business and investment property placed in service after 1986 and consisting of the alternative and general depreciation systems (IRS, 2018c). 
N

net present value (NPV) Present value of a project's escalated future cash flows minus the initial cost, salvage, and other returns (Stermole, 1974).

\section{0}

order-of-magnitude estimate A cost-scoping activity to determine the overall amount or limits of expenditure from minimal information (Bredehoeft, Dysert, and Hollmann, 2019).

\section{$\mathbf{R}$}

rate-of-return (ROR) Interest rate after dividing after-tax average annual profits by the average investment (Investopedia, 2019).

reclamation bond Prerequisite for obtaining a coal mining permit to ensure that the regulatory authority will have sufficient funds to reclaim it the permittee fails to complete the reclamation plan approved in the permit (Office of Surface Mining Reclamation and Enforcement, 2017).

recovery period The number of project years over which to depreciate or otherwise recapture a cost associated with a property class identification (IRS, 2018c).

reserves (coal) Economically recoverable coal that may be extracted considering environmental, legal, and technologic constraints (Wood and others, 1983).

resources (coal) Naturally occurring coal deposits that are classified by their geological certainty and potential for economic viability (Wood and others, 1983).

return-on-investment (ROI) Profitability measure that evaluates business performance by dividing net profit by net worth (Entrepreneur, 2019).

\section{S}

salvage Estimated value of an asset at the end of its useful life, which is not depreciated under the modified accelerated cost recovery system (IRS, 2018c).

simple interest (add-on or flat) Application of interest to investment principal each interest period (Stermole, 1974).

stochastic Pertaining to random variables (Lapedes, 1978).

stripping ratio The unit amount of spoil or waste that must be removed to gain access to a similar unit amount of ore or mineral material (Thrush, 1968).

\section{T}

time value of money Money available now is worth more than the same amount in the future due to its potential earning capacity (Investopedia, 2019).

\section{U}

useful life An estimate of how long an item of property can be expected to be useable in business or produce income (IRS, 2018c).

W

working capital An amount of cash set aside on corporate financial statements to compensate for investment shortfalls (IRS, 2018c). 


\section{Appendix 1. Quality Control}

Economic evaluations of mining operations are prepared in accordance with the guidelines, recommended practices, and standards specified in this report. The rigorous application of sound economic principles and practices rely on a background founded by recognized authorities. These authorities include AACE International (AACE), American National Standards Institute, U.S. Department of Energy (DOE), U.S. Internal Revenue Service (IRS), and Investment Evaluations Corporation, as described below.

- $A A C E$. - AACE is a costing and management certifying authority founded in 1956 and accredited by the Council of Engineering and Scientific Specialty Boards. Each AACE practice is a peer-reviewed standard that is supported by external expert commentary.

- American National Standards Institute.-Standard Z94.0 provides a description of three estimation class distinctions: Order-of-magnitude, Budget, and Definitive.

- DOE.-DOE's Office of Management Oversight and Assessments adopted practices similar to AACE practices in its Cost Estimating Guide (DOE G 413.3-21), and prepared memorandums of understanding with AACE in 1997, 2002, and 2007 (AACE, 2012).

- IRS.-Provides guidance for the treatment of capital and operating costs through selected publications and U.S. tax law.

- Investment Evaluations Corporation.-Discusses economic principles and practices at the Colorado School of Mines (Golden, Colorado) in its course titled "Economic Evaluation \& Investment Decision Methods" and the book with the same name.
AACE provides recommended practices that are especially useful in mitigating the risk of reaching an economic goal. For U.S. Geological Survey coal assessments, this risk is mitigated using a cash contingency to insure an adequate investment amount for recovering a coal resource. Table 1.1 provides a selection of AACE recommended practices for total cost management. The inclusion of similar and almost identical language in DOE G 413.3-21 standards illustrates that these common principles and practices are used in Federal government economic analyses (DOE, 2018).

The IRS regards mining ventures as potential incomeproducing entities that are entitled to certain investment treatments. Mining ventures, if properly stimulated, become tax resources for Federal, State, and local income benefit. Owners, including individuals, investment groups, and corporations, have often entered into cooperative agreements that provide private and public advantage. From these agreements comes a body of law applicable to private businesses. Selected IRS business guidelines that provide standards for identifying taxable items and their handling are provided in table 1.2. Provisions included in these standards may be changed through legislation, agency rulemaking, or IRS-corporate negotiations.

Conceptual mining design for national coal assessments is based on analogs, which are regional mining operations recovering coal from similar geological conditions. All active and standby U.S. mines and their contractors are included in a Federal database that is continually updated through required reporting by owner corporations and individuals. This information is available online through the U.S. Department of Labor Mine Safety and Health Administration website (Mine Safety and Health Administration, 2019). This registry assigns a seven-digit mine identification number to each mine. Additional information from reliable, unspecified sources may also be included in U.S. Geological Survey coal assessments. 
Table 1.1. Selection of practices recommended by AACE International for total cost management. ${ }^{1}$

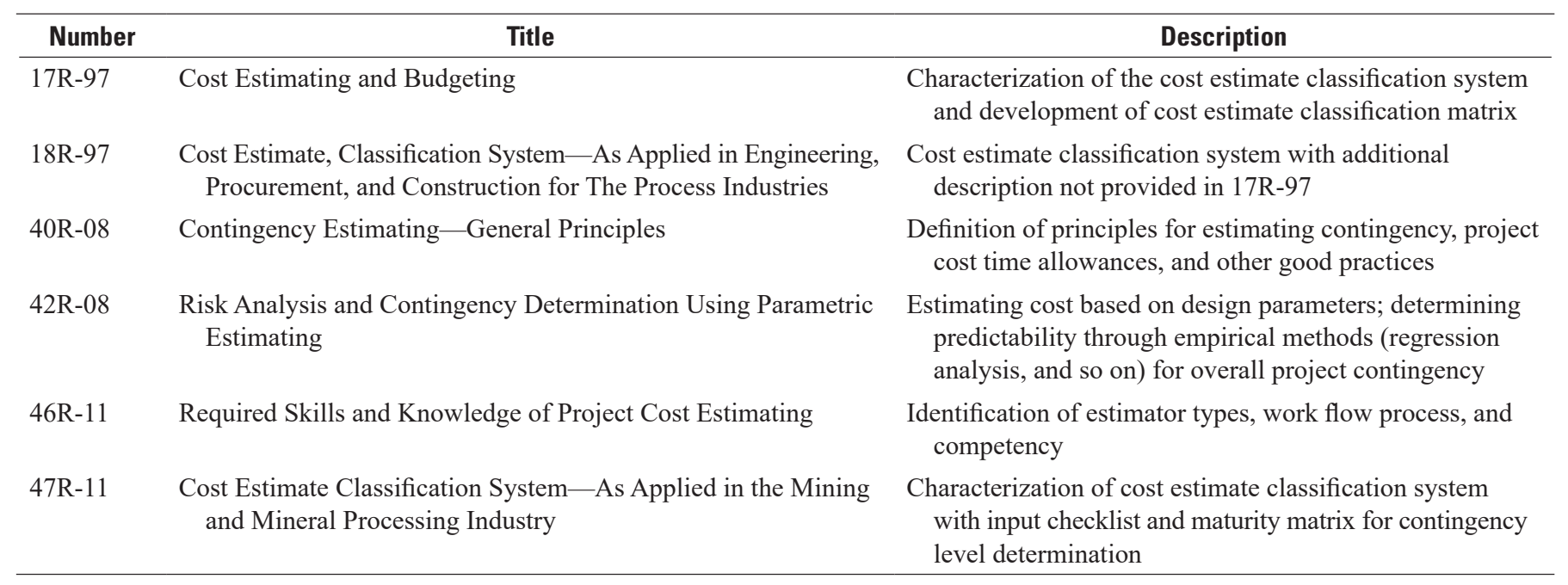

${ }^{1}$ Total cost management framework, a subset of the cost estimate classification system.

Table 1.2. Internal Revenue Service (IRS) business guidelines.

[MACRS, modified accelerated cost recovery system]

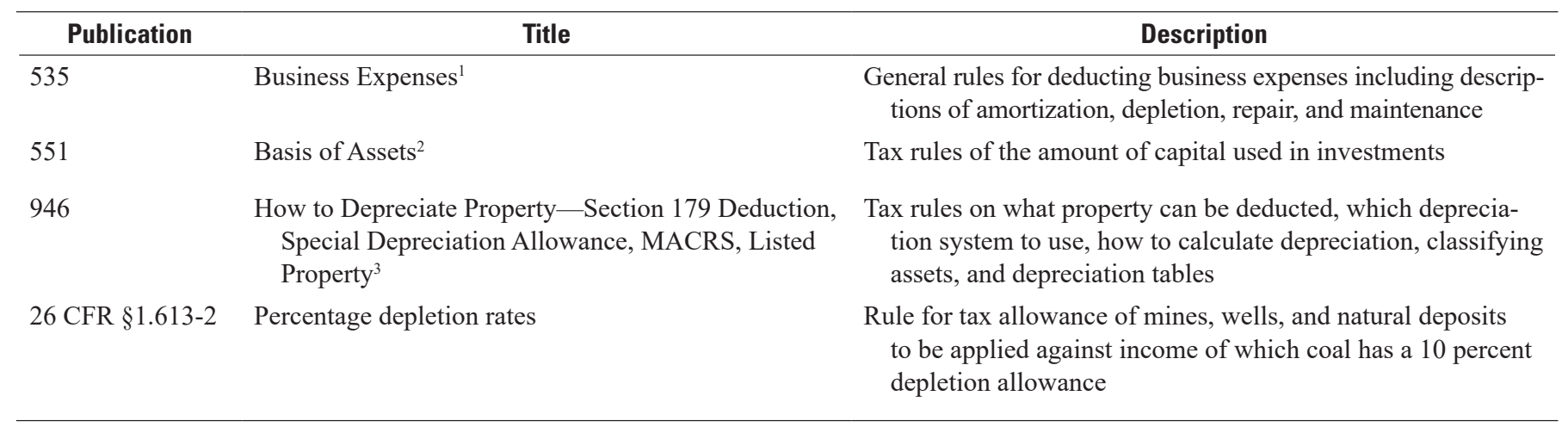

${ }^{1}$ Internal Revenue Service, 2018b.

${ }^{2}$ Internal Revenue Service, 2018a.

${ }^{3}$ Internal Revenue Service, 2018c. 


\section{Appendix 2. Alternative Depreciation System Methods}

Methods pertaining to the economic evaluation of national coal assessments that are detailed in this report include straight line, declining balance, unit-of-production, and lump-sum depreciation. Concepts of class life and capital recovery are also discussed.

\section{Tax Law and Depreciation}

Depreciation is an allowable tax deduction that recovers the expense of placing an asset into service over time. Methods used in national coal assessments are straight line, declining balance, unit-of-production, and lump-sum (expensing) depreciation. These are permitted by the Internal Revenue Service (IRS) in accordance with guidance provided in IRS Publication 946 (IRS, 2018c). Rules pertaining to depreciation are given in the modified accelerated cost recovery system (MACRS), which was established for capital recovery of investment property placed in service after 1986. MACRS consists of two depreciation systems: the alternative depreciation system (ADS) and the general depreciation system (GDS).

ADS must be used for corporations with 50 percent or less interest in a mining venture, tangible property used outside the United States, tax exempt issues, and farming. ADS can seldom be applied to U.S. Geological Survey (USGS) coal assessments unless special conditions in a coal-bearing region make this alternative appropriate. Instead of ADS, the provisions of GDS are generally used in performing current economic evaluations within the continental United States.

\section{Class Life and Capital Recovery}

The return, or recovery, of capital that was spent to purchase assets, such as equipment, is allowed under tax rules as a means of stimulating additional investment for overall economic benefit. Profit is determined by subtracting the purchase price of an asset, such as a machine, from the income that it produces; this profit is the return-on-investment or capital recovery. An asset, such as a machine or other property, may have a tax life (class life) that is shorter than its useful life. Class lives for various assets under the GDS of MACRS have capital recovery periods as shown in tables B-1 and B-2 of IRS Publication 946. Selected categories that are used in USGS coal assessments are shown in table 2.1. The recovery period specifies the number of years during which a cost can be recaptured. This abbreviated listing excludes assets that do not apply to most mining projects.

For USGS coal assessments, the Section 1250 property capital recovery period shown in table 2.1 applies to all mine and process buildings at the primary mine plant site. These facilities are depreciated by the straight line method over 39 years using the mid-month convention as specified in IRS Publication 946 (IRS, 2018c). The facilities are placed in service by year, which allows 1.391 percent depreciation allocation during the first year, 2.564 percent during years $2-39$, and 1.177 percent during year 40 (IRS, 2018c, table A-7a).

Some estimators may find the IRS capital recovery period problematic, especially when published equipment lives as shown in table 2.2 exceed 7 years or $12,000-15,000$ hours. An

Table 2.1. Asset class lives and recovery periods (modified from Internal Revenue Service, 2018c).

\begin{tabular}{|c|c|c|}
\hline Description of assets & $\begin{array}{c}\text { Class life } \\
\text { (years) }\end{array}$ & $\begin{array}{c}\text { Recovery } \\
\text { period } \\
\text { (years) }\end{array}$ \\
\hline \multicolumn{3}{|l|}{ Office furniture, fixtures, and equipment } \\
\hline $\begin{array}{l}\text { Includes furniture and fixtures that are not a structural component of a building, such as desks, files, safes, and com- } \\
\text { munication equipment }\end{array}$ & 10 & 7 \\
\hline \multicolumn{3}{|l|}{ Light general-purpose trucks } \\
\hline \multicolumn{3}{|l|}{ Heavy general-purpose trucks } \\
\hline $\begin{array}{l}\text { Includes heavy general-purpose trucks, concrete ready-mix trucks, and ore trucks for use over the road (actual } \\
\text { unloaded weight of } 13,000 \text { pounds or more) }\end{array}$ & 6 & 5 \\
\hline \multicolumn{3}{|l|}{ Land improvements } \\
\hline $\begin{array}{l}\text { Includes improvements directly to or added to land, whether such improvements are Section } 1245 \text { property (electri- } \\
\text { cal transmission property used for } 69 \text { or more kilovolts) or Section } 1250 \text { property (nonresidential real property } \\
\text { such as office building or warehouse), provided such improvements are depreciable. Examples of such assets } \\
\text { include sidewalks, roads, canals, waterways, drainage facilities, sewers (not including municipal sewers in Class 51), } \\
\text { wharves and docks, bridges, fences, landscaping shrubbery, or radio and transmitting towers }\end{array}$ & 20 & 15 \\
\hline \multicolumn{3}{|l|}{ Mining } \\
\hline $\begin{array}{l}\text { Includes assets used in the mining and quarrying of metallic and nonmetallic minerals (including sand, gravel, } \\
\text { stone, and clay) and the milling, beneficiation and primary preparation of such minerals }\end{array}$ & 10 & 7 \\
\hline
\end{tabular}


asset's class life and its recovery period are determined based on economic benefits and not physical duration although the IRS has not uncoupled these aspects entirely. A mining asset such as a dragline may operate for 30 years but the dragline is depreciated in 7 years according to IRS rules. Thus, the asset life does not equal the apparent useful life of the overall machine. However, the dragline is a system of components (including motors, drives, ropes, electrical units, and various mechanical moving parts) that wear out at different times. Before a dragline is scrapped, its components may be overhauled many times. Capital recovery periods of 5, 7, 15, and 39 years continue to be the basis for depreciating assets in USGS coal assessment life-of-mine cost estimates.

\section{Straight Line Depreciation}

Straight line depreciation is an acceptable cost recovery method under MACRS GDS and is commonly used in mining economic studies. A convention is selected that places an asset or assets into service at some point within a startup year. An asset or group of assets can be placed into service during any month, quarter, or at mid-year. Should a mid-year convention be used, an asset with a depreciable life of 5 years will be allowed to depreciate 10 percent during years 1 and 6 and 20 percent may be depreciated during years 2, 3,4, and 5. Likewise, a 7-year recovery period will have a first and last year rate of 7.14 percent and intervening years of 14.29 percent (IRS, 2018c, table A-8). A straight line half-year convention means that an asset is placed in service at mid-year so that one-half of the allowed depreciation occurs during the first and last years of the recovery period. Straight line depreciation is sometimes used in economic studies for mining ventures when an accelerated method would be more appropriate. However, straight line depreciation may be advantageous when assets with high salvage and low maintenance costs are used or when higher cost recovery is needed during later years of a project.

Depreciation rules attempt to cover the physical life of an asset but often the physical life extends longer than the depreciable life (class life). Most mining assets have a designated class life of 10 years with a capital recovery of 7 years. Should the asset be used for 5 more years, the asset value may be partially depreciated during years 1 and 8 with the remaining depreciation taken during the intervening years. The asset will have no tax deductibility for years $9,10,11$, and 12 . Straight line depreciation is misapplied when the asset cost is divided by 12 rather than 7 .

\section{Declining Balance Depreciation}

Accelerated depreciation is an option that can be advantageous to certain tax-savvy corporations as it quickly returns capital through tax savings and the capital can be immediately reinvested in other projects to improve the company's financial profile. Accelerated depreciation is advantageous for USGS coal

Table 2.2. Suggested service life of equipment.

[NA, not applicable]

\begin{tabular}{|c|c|c|c|}
\hline Machinery & Recommended service life (hours) & Recommended service life ${ }^{2}$ (hours) & Assessment service life $^{3}$ (hours) \\
\hline Conveyors & 10,000 & NA & 10,000 \\
\hline Crushers & $26,000-52,000$ & NA & 45,000 \\
\hline \multicolumn{4}{|l|}{ Dozers (track) } \\
\hline Medium size & NA & $10,000-15,000$ & 12,000 \\
\hline Large size & NA & $15,000-22,000$ & 18,000 \\
\hline Draglines & $45,000-65,000$ & NA & 55,000 \\
\hline Drills & $12,000-18,000$ & NA & 15,000 \\
\hline Excavators (backhoes) & $10,000-14,000$ & $8,000-12,000$ & 10,000 \\
\hline Front-end loaders (wheel) & NA & $10,000-15,000$ & 12,000 \\
\hline \multicolumn{4}{|l|}{ Motor graders } \\
\hline Reclamation & NA & $12,000-20,000$ & 12,000 \\
\hline Road maintenance & NA & NA & 15,000 \\
\hline Pumps & 12,000 & NA & 12,000 \\
\hline Scrapers & NA & $8,000-16,000$ & 8,000 \\
\hline Shovels & 25,000 & NA & 18,000 \\
\hline Trucks (coal haulers) & 37,500 & $15,000-25,000$ & 25,000 \\
\hline
\end{tabular}

${ }^{1}$ InfoMine, 2016.

${ }^{2}$ Caterpillar, 1979.

${ }^{3}$ Author's assumption. 
assessment projects because it produces an optimum cash flow at a time when capital should best be reinvested or when a mining project should be terminated. Depreciation can be calculated by using the 200-percent declining balance method or the 150-percent declining balance method. These methods are specifically tied to certain asset recovery periods as shown in table 2.3. As the table shows, mining assets are not designated for 10-, 20-, and 25-year recovery periods. Any recovery period beyond 20 years must be depreciated using the straight line method. Straight line depreciation can be used for any recovery period.

IRS Publication 946 provides tables of values for declining balance rates, or the rates may be calculated for 200-percent declining balance depreciation as shown in table 2.4.
Often, straight line depreciation is used for economic studies of mining ventures when an accelerated method would be more appropriate, as demonstrated in table 2.5. Halfway through the depreciation period, accelerated depreciation provided a nearly $\$ 2.6$ million advantage over the straight line method. This amount might be reinvested in another asset or the project life could be shortened and still provide favorable economic return. However, straight line depreciation may be advantageous when assets with high salvage and low maintenance are used or when higher cost recovery during later years is needed.

Table 2.3. General depreciation system (GDS) for depreciable mining property (from IRS, 2018c).

$[\%$, percent $]$

\begin{tabular}{|c|c|c|}
\hline Asset recovery period & Property & Depreciation method \\
\hline 3-year property & Tractor units for over-the-road use & $200 \%$ declining balance \\
\hline 5-year property & $\begin{array}{l}\text { Automobiles and trucks; including both light and heavy trucks (less than and } \\
\text { more than 13,000 pounds, respectively) such as general purpose and ore haulers } \\
\text { Data handling equipment including typewriters, calculators, and copiers } \\
\text { Information systems including computers and peripheral equipment } \\
\text { Any property used in research and experimentation }\end{array}$ & $200 \%$ declining balance \\
\hline 10-year property & No applicable mining assets defined & $200 \%$ declining balance \\
\hline 15 -year property & $\begin{array}{l}\text { Certain land improvements (landscaping, fences, roads, and bridges) } \\
\text { Electric transmission property used in the transmission at } 69 \text { or more kilovolts of } \\
\text { electricity placed in service after April } 11,2005 \\
\text { Conveyors }\end{array}$ & $150 \%$ declining balance \\
\hline Nonresidential rental property & No applicable mining assets defined & Straight line \\
\hline $\begin{array}{l}\text { Nonresidential real property } \\
\text { (39-year property) }\end{array}$ & Office buildings and warehouses (Section 1250 property) & Straight line \\
\hline
\end{tabular}

Table 2.4. Calculation of 200-percent declining balance (from IRS, 2018c).

\section{Description}

$\$ 1,000$ capital asset to be depreciated in 5 years using half-year convention for 200-percent declining balance depreciation.

One-fifth of the asset is depreciated in years 1 and 6 and two-fifths are depreciated in years 2, 3, 4, and 5. Depreciable amounts are then subtracted from subsequent year's capital asset value until the year following the depreciation period.

\begin{tabular}{|c|c|c|}
\hline Year & Calculation & Depreciable amount \\
\hline 1 & $\$ 1,000 \times 1 / 5=\$ 200$ & $\$ 200$ \\
\hline 2 & $\$ 1,000-\$ 200=\$ 800 \times 2 / 5=\$ 320$ & $\$ 320$ \\
\hline 4 & $\$ 1,000-(\$ 200+\$ 320+\$ 192)=\$ 288 \times 2 / 5=\$ 115$ & $\$ 115$ \\
\hline 5 & $\$ 1,000-(\$ 200+\$ 320+\$ 192+\$ 115)=\$ 173 \times 2 / 5=\$ 69$ & $\$ 69$ \\
\hline
\end{tabular}




\section{Unit-of-Production Depreciation}

Unit-of-production depreciation avoids class life designations by only including the number of actual units that are produced before an asset is worn out. This method is mainly used in depreciating manufacturing machinery. More depreciable value is charged when machines have higher activity and less is charged when there is a low level of activity. Zero depreciation is charged when machinery is idle. This depreciation method has possible advantages for mining, as well as general earthwork. Calculation of this method is shown in table 2.6.
If the truck in the table 2.6 example is used on a sporadic or discontinuous basis, its partial use would result in far less volume being hauled than the truck is capable. As a result, depreciation would be decreased for that year, the depreciable life would likely be extended, and the salvage might be decreased. When applied to discontinuous production, accelerated or straight line depreciation does not provide the tax advantage that is provided by the unit-of-production method. Assessments of coal basins in which continuous operations for mining analogs is lacking will be better served by using this depreciation method.

Table 2.5. Calculation of comparative accelerated and straight line depreciation.

\section{Description}

Comparison of 200-percent declining balance and straight line methods for depreciating surface mining equipment

Equipment - Shovel-truck overburden removal and wheel loader-truck coal recovery

Production-11.1 million cubic yards of overburden removal and 2.0 million short tons coal recovery

Initial capital investment $-\$ 13,823,000$

Cost recovery period, as designated by the Internal Revenue Service (2018c) - 7 years

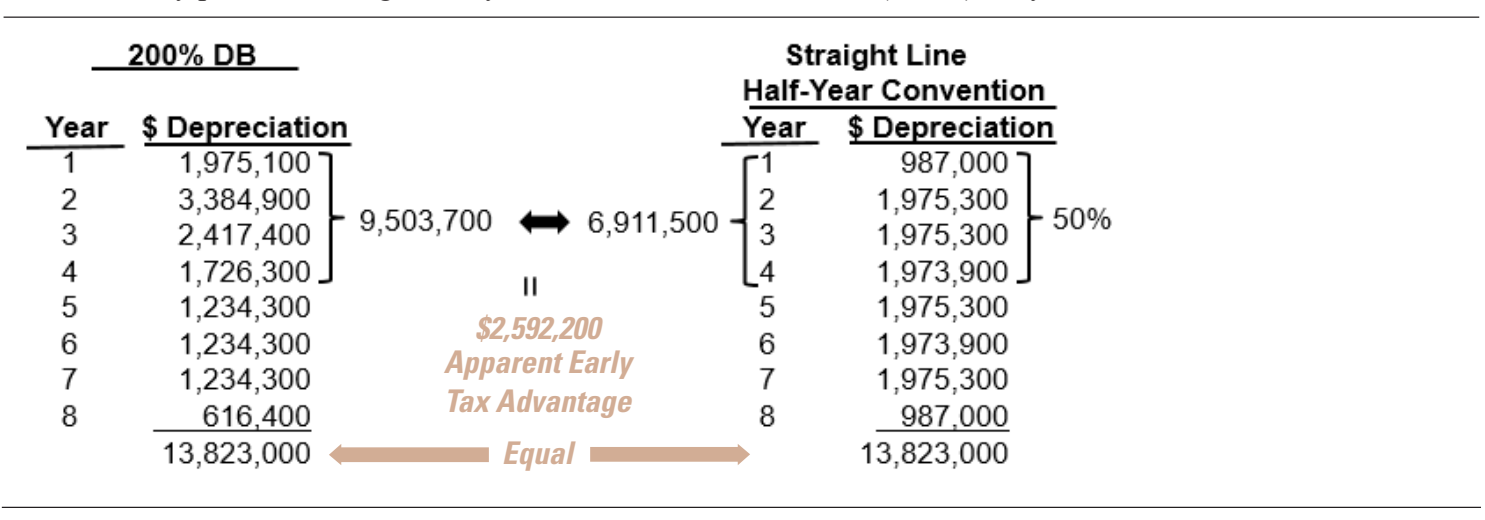

Table 2.6. Calculation of unit-of-production depreciation.

$$
\begin{aligned}
& \text { Description } \\
& \text { Purchase of a 100-ton rear dump haulage truck }{ }^{1} \\
& \text { Cost }-\$ 1,000,000 \\
& \text { Salvage- } \$ 250,000 \\
& \text { Unit life-16.0 million cubic yards (cyds) } \\
& \text { Average annual units-3.2 million cyds } \\
& \text { Depreciation }=\frac{\text { Number of units produced }}{\text { Number of Lifetime units }} \times(\text { Cost }- \text { Salvage value }) \\
& \text { Depreciation }=\frac{3.2 \text { million cyds }}{16.0 \text { million cyds }} \times(\$ 1,000,000-\$ 250,000) \\
& \text { Depreciation }=\$ 150,000 \text { per year }
\end{aligned}
$$

Truck can be expected to last for 5 years in this case.

\footnotetext{
${ }^{1}$ Nominal quantities to demonstrate calculation only.
} 


\section{Lump-Sum Depreciation (Expensing)}

Another means to rapidly save taxes through depreciation is provided in Section 179 of the U.S. tax code, which is the act of expensing. Expensing allows for an asset to be depreciated totally during the first year that it is put into service. However, as shown in table 2.7, expensing is restricted by three limits: the first limit is $\$ 500,000$, the second limit is $\$ 2$ million, and the third limit is $\$ 2.5$ million.

The Section 179 deduction example in table 2.7 illustrates some of the inexplicable details of the U.S. tax law and how depreciation can be manipulated. A small corporation may be most affected by how it depreciates its assets and may direct the cost estimator to consider multiple smaller equipment units to maximize a tax advantage. USGS economic evaluations may use this depreciation method, in part, where an analog representing small coal operations predominate in a coalfield.

A Section 179 deduction might also be combined with declining balance depreciation as described in table 2.8. A maximum $\$ 500,000$ expense is taken during the first year with the remaining $\$ 500,000$ depreciated either by declining balance or straight line depreciation. Clearly, by using declining balance, a $\$ 140,500$ tax advantage is realized.

Table 2.7. Calculation of lump-sum (expensing) depreciation.

[IRS, Internal Revenue Service. Shading indicates not applicable]

Description
Purchasing either a 11-, 16-, or 26-cubic yard capacity wheel loader costing $\$ 1,673,000, \$ 2,050,000$, or $\$ 4,673,000$, respectively

11-cubic yard capacity wheel loader

A maximum of $\$ 500,000$ can be expensed, which leaves $\$ 1,173,000$ to be depreciated during the next 7 years, as specified in Chapter 2 of IRS Publication 946 (IRS, 2018c).

\begin{tabular}{ccc} 
Cost - Limit $1=$ Remaining & Remaining to be depreciated by other method & Expensed \\
$\$ 1,673,000-\$ 500,000=\$ 1,173,000$ & $\$ 1,173,000$ & $\$ 500,000$ \\
\hline
\end{tabular}

16-cubic yard capacity wheel loader

The first and second limits of \$500,000 and \$2 million apply, as specified in Chapter 2 of IRS Publication 946 (IRS, $2018 \mathrm{c}$ ).

\begin{tabular}{|c|c|c|}
\hline Cost - Limit $2=$ Remaining & Remaining to be depreciated by other method & Expensed \\
\hline $\begin{array}{c}\$ 2,050,000-\$ 2,000,000=\$ 50,000(\text { reduces } \\
\text { Limit } 1)\end{array}$ & & \\
\hline \multicolumn{3}{|l|}{ Cost - Limit $1=$ Expensed } \\
\hline$\$ 500,000-\$ 50,000=\$ 450,000(\mathrm{New}$ Limit $)$ & & $\$ 450,000$ \\
\hline \multicolumn{2}{|l|}{ Cost - New limit $=$ Remaining } & \\
\hline
\end{tabular}

26-cubic yard capacity wheel loader

The purchase price exceeds the \$2.5 million maximum limit. As specified in Chapter 2 of IRS Publication 946 (IRS, $2018 \mathrm{c}$ ), a Section 179 deduction cannot be taken.

Table 2.8. Calculation combining expensing with accelerated and straight line depreciation.

Description

Purchase of a 100-ton rear dump haulage truck at $\$ 1,000,000$

$\$ 500,000$ expensed during first year of service under Internal Revenue Service (IRS) Section 179 rule (IRS, 2018c)

Remaining $\$ 500,000$ to be depreciated using 200-percent declining balance or straight line depreciation method

\begin{tabular}{lll}
\hline & \multicolumn{1}{c}{ Declining balance } & \multicolumn{1}{c}{ Straight line' $^{1}$} \\
\hline Year 1 & $\$ 500,000$ (expensed) & $\$ 500,000$ (expensed) \\
Year 2 & $\$ 228,000$ & $\$ 87,500$ \\
Total & $\$ 728,000$ & $\$ 587,500$ \\
\hline
\end{tabular}

${ }^{1}$ Select depreciating convention that provides maximum value at 17.5 percent for 5 -year life-Mid-Quarter, placed in service in first quarter of second year (see table A-9 of IRS Publication 946 [IRS, 2018c]). 

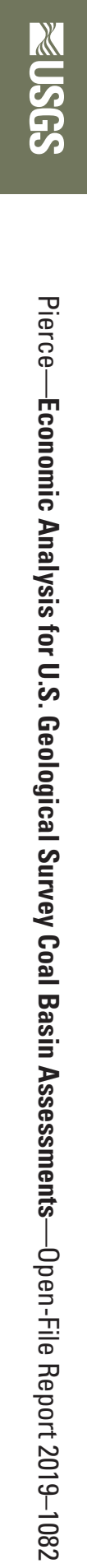